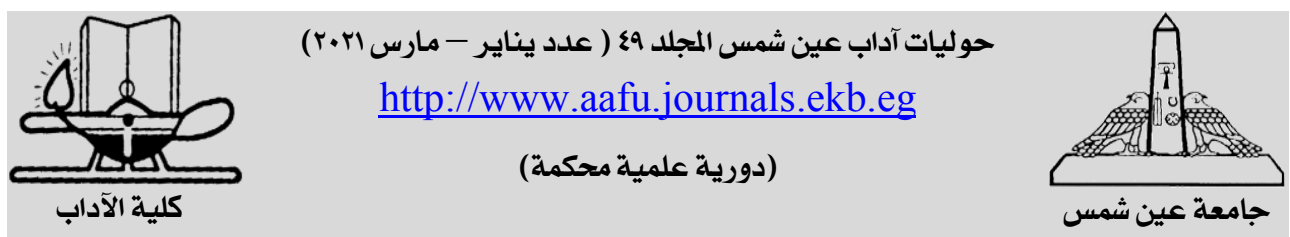

\title{
استدعاء الثخصيات التراثية في شعر حسن عبد الله القرشي
}

\section{زهير حسن سعيد العمري*}

أستاذ الدراسات الأدبية المشارك- قسم اللغة العربية- كلية العلوم والآداب - جامعة نجران- المملكة العربية السعودية لاية السلة

\section{zhalamri@nu.edu.sa}

تتخذ العودة إلى التراث ومصادره المختلفة في الشعر المعاصر أبعاداً مختلفة

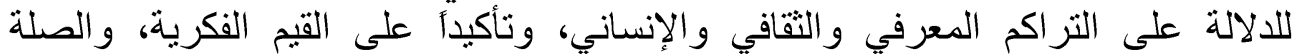
التاريخية الوثثقة التي تربط الإنسان المعاصر بمكوناته التاريخية، والتي بيتمد منها قوتئه

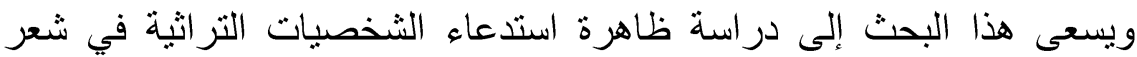

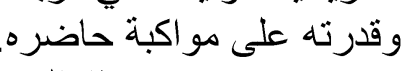

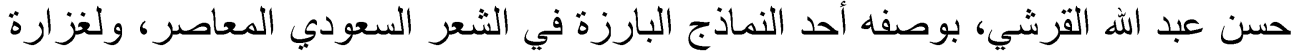

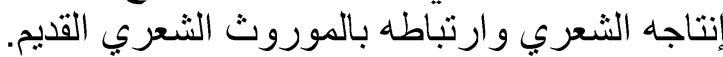

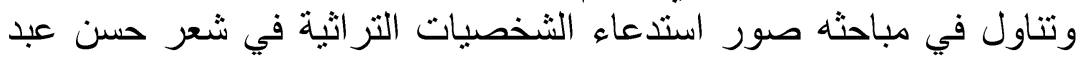

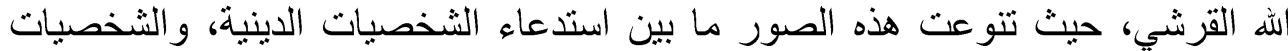
التاريخية، والثخصيات الأدبية، والثخصيات الأسطورية. كما يعرض الثياء البحث لأنماط استدعاء الثخصيات التر اثية بنو عيه الكلي، والثية والجزئي.

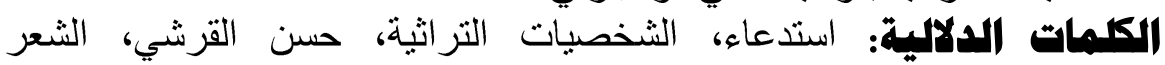

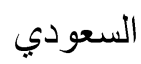




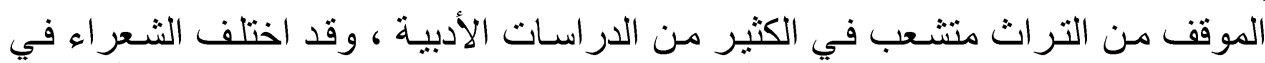

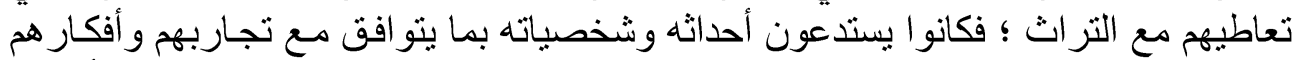

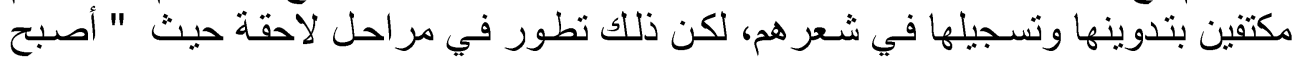

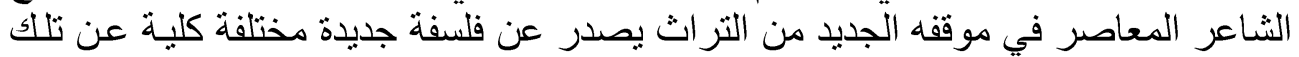

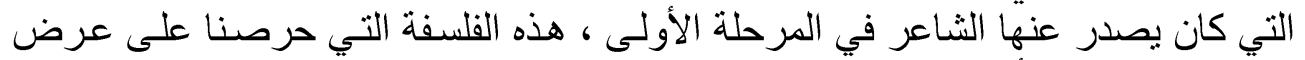

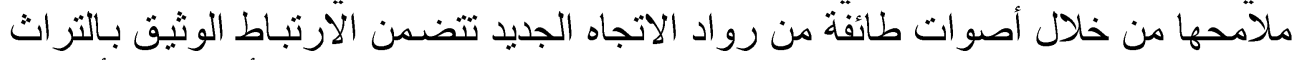

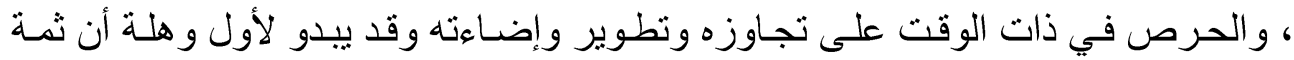

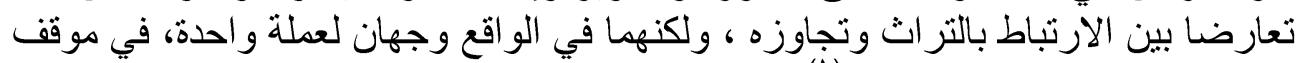

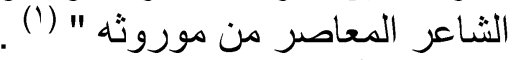

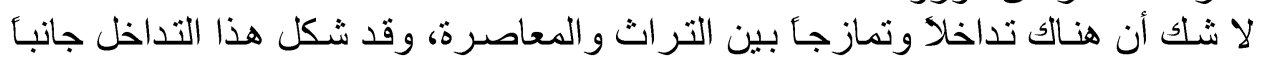

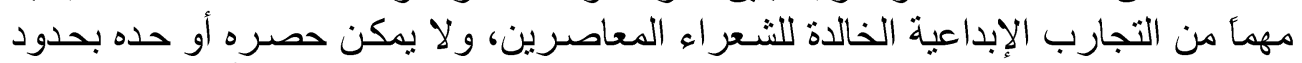

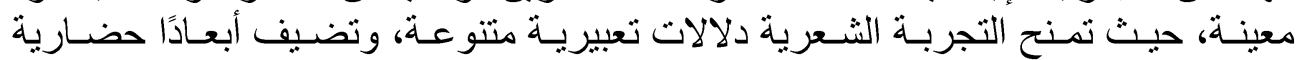

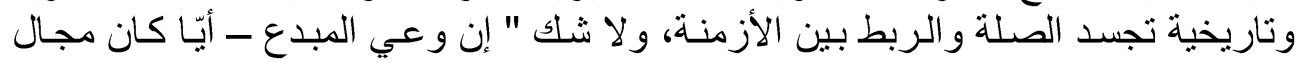

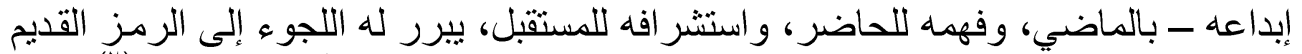

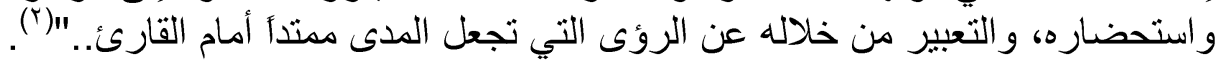

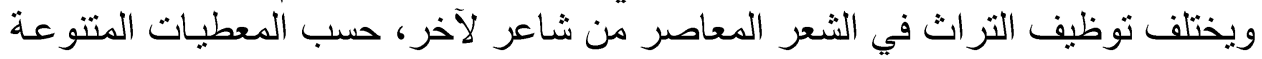

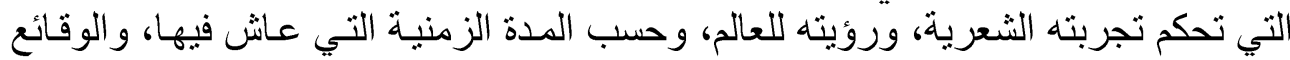
التاريخية التي حدثت في زمنه.

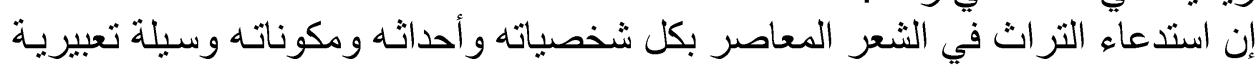

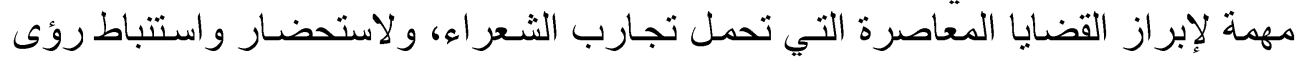

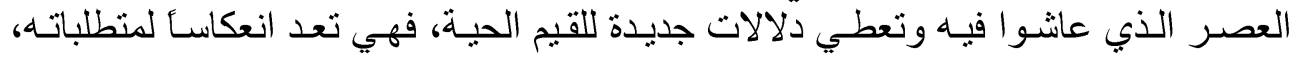

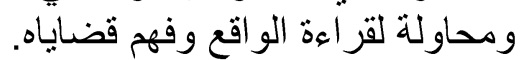

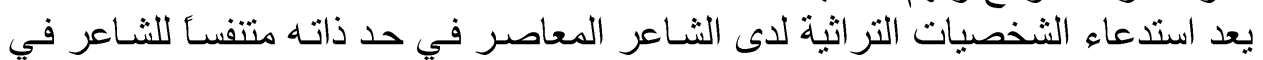

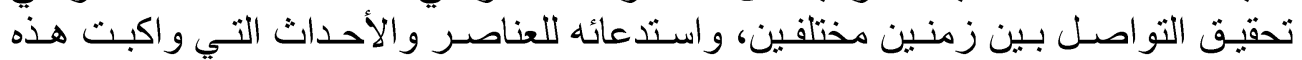

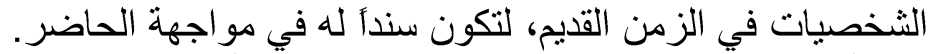

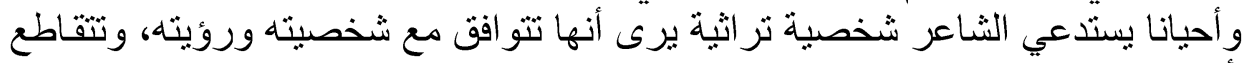

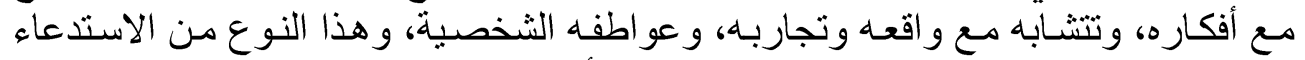

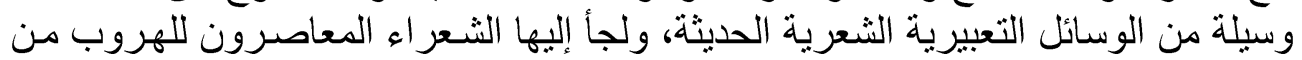

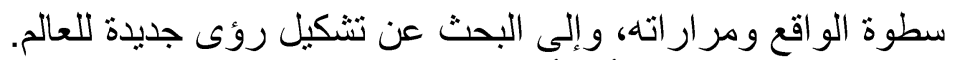

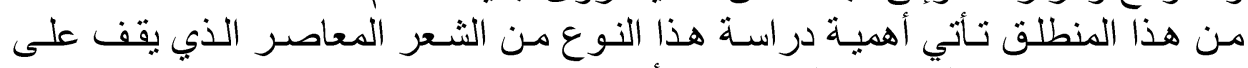

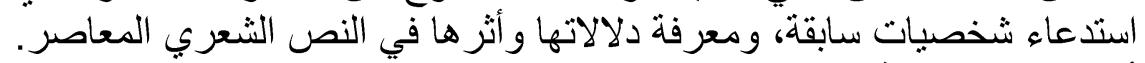

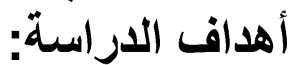

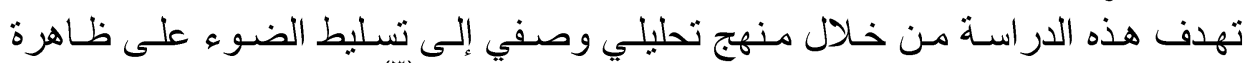

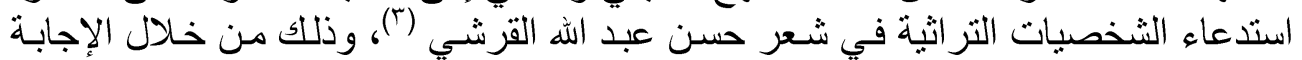
عن مجمو عة من التساؤلات، منها:

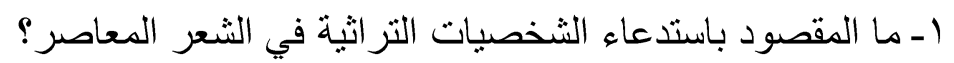

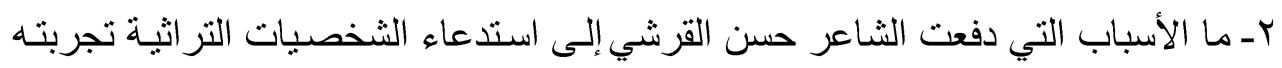


rـ ما أنماط استدعاء الشخصيات التر اثية في شعر حسن القرشي؟

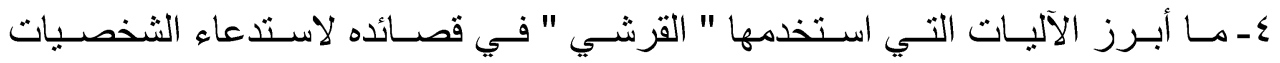

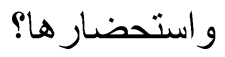

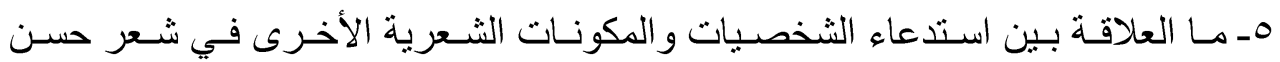

$$
\text { القرشي؟ }
$$

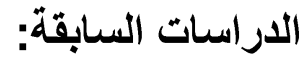

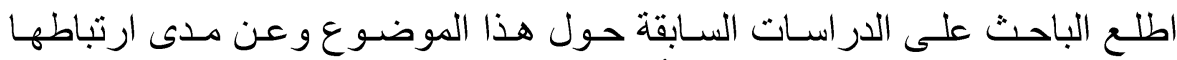

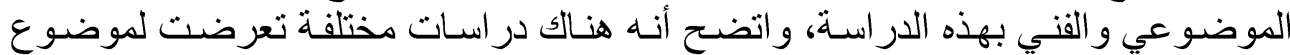

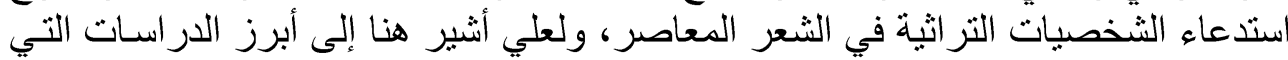

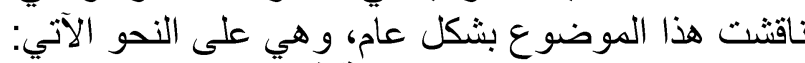

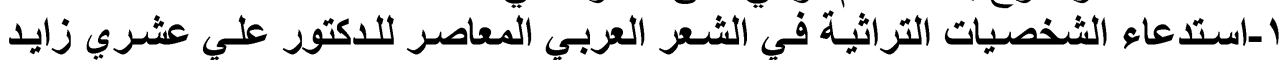

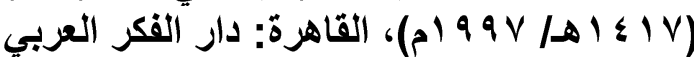

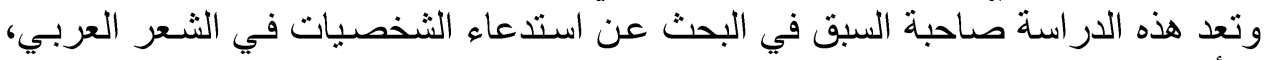

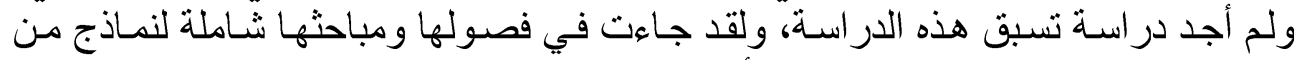

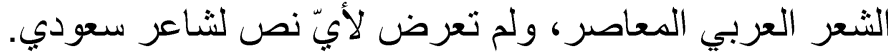

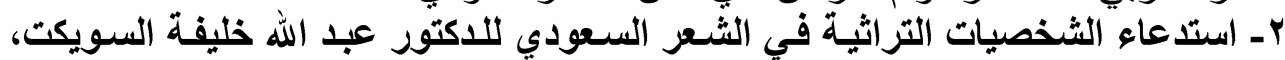

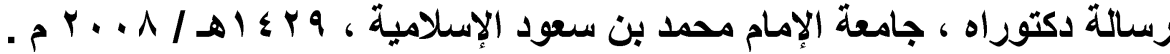

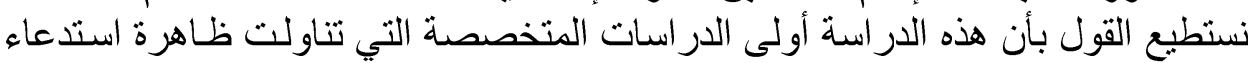

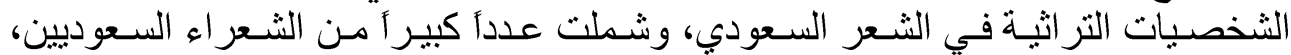

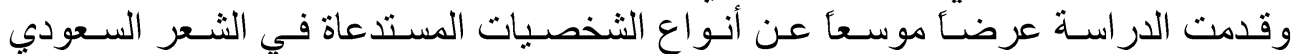

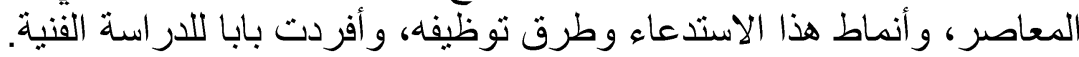

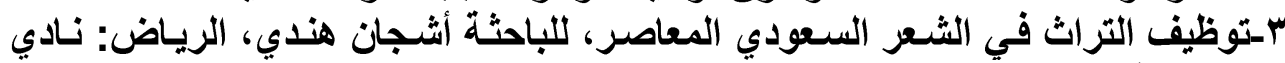

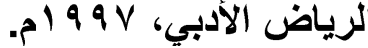
جاءت هذه الدراسة شاملة و عامة عرضت لظاهرة توظيف التراثل في الثـعر السعودي

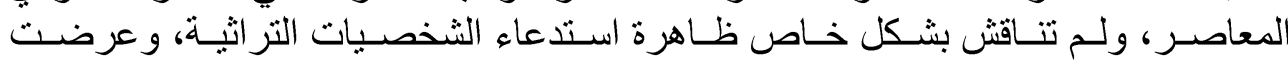

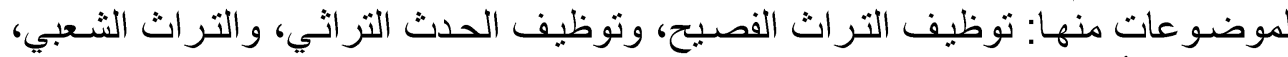

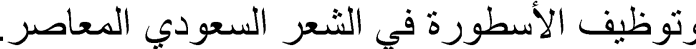

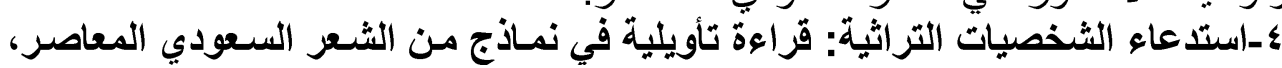

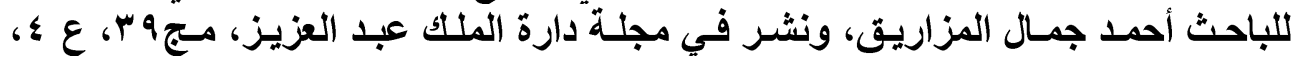

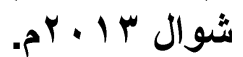

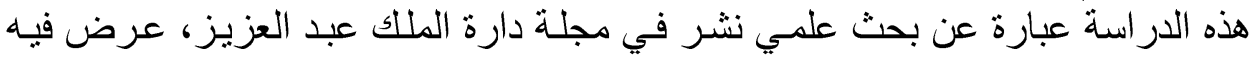

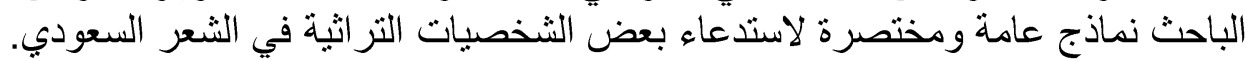

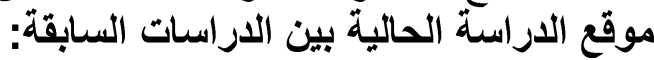

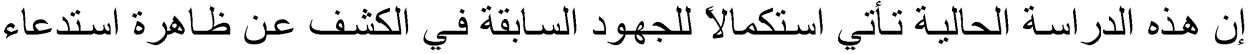

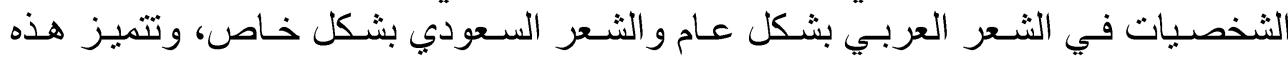

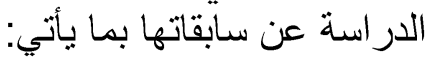

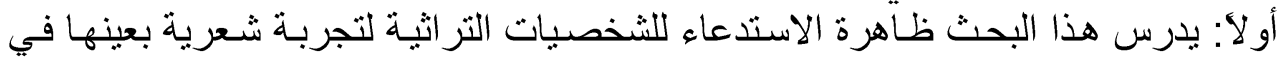
در اسة تفصيلية تقف على مكامن صور الاستدعاء و أنماطه وطرق توظئيفه. 


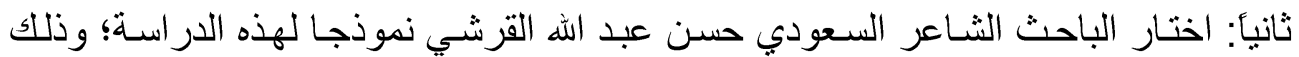

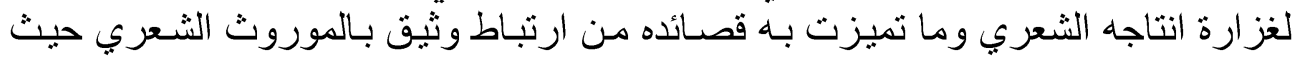

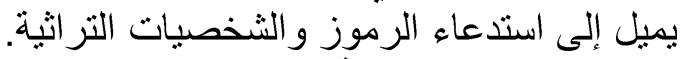
معنى (الاستد عاء) لغة الغة:

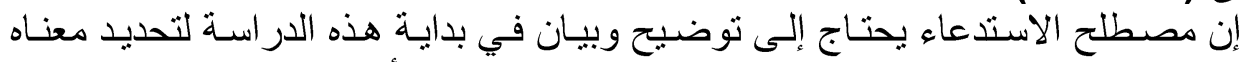

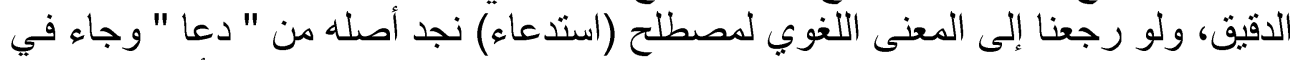

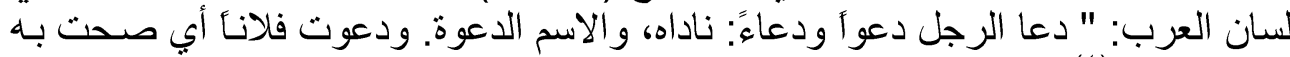

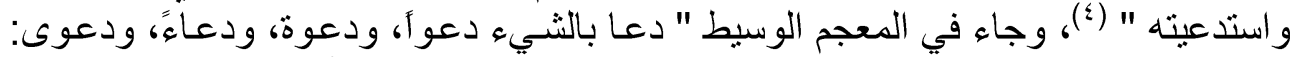

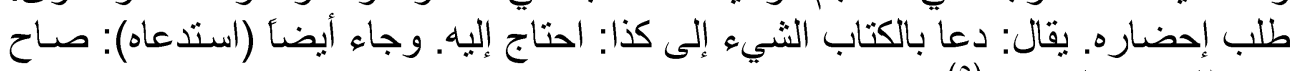

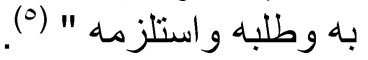

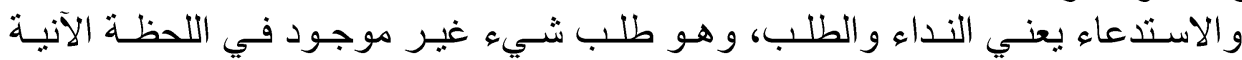

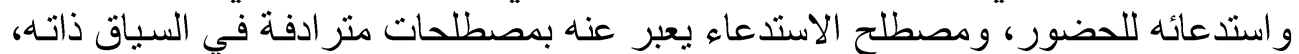

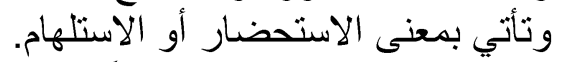
معنى (الاستدعاء) الصطلاحاً:

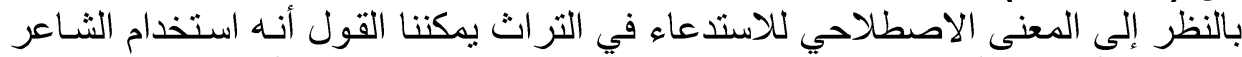

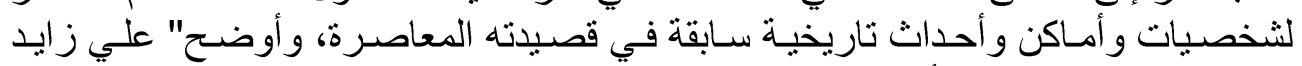

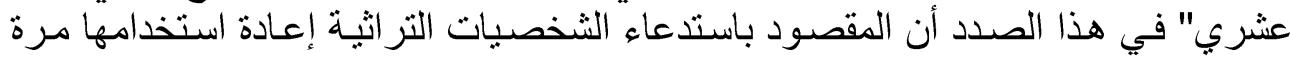

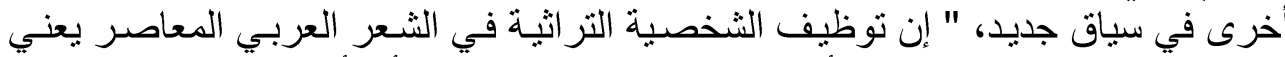

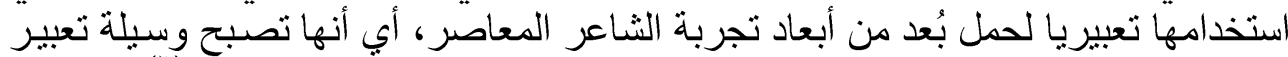

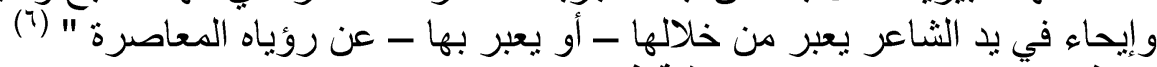

لماذا استثاء فاء الثخصيات التراثية في الثعر المعاصر؟ لهاء

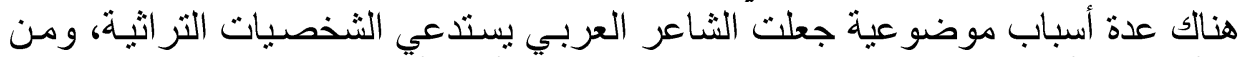

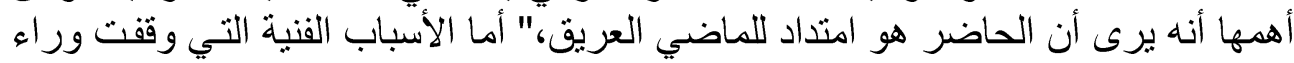

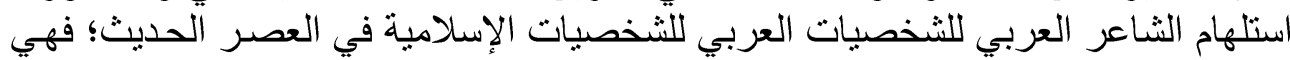

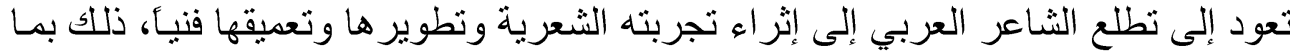

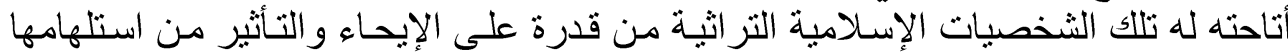

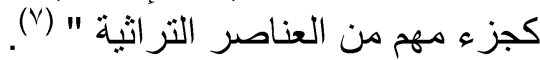

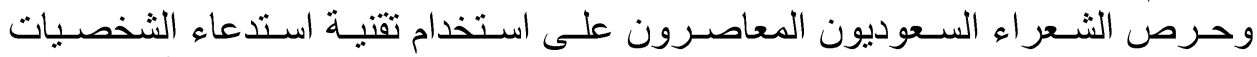

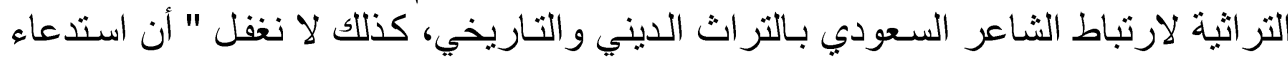

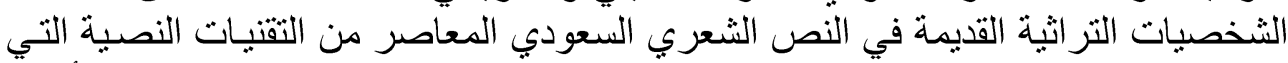

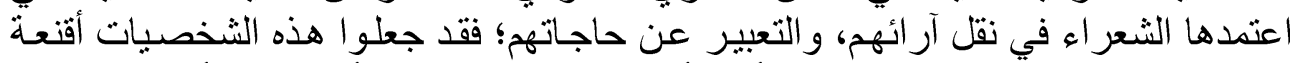

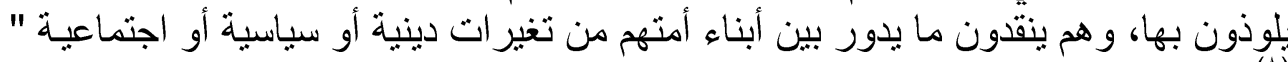

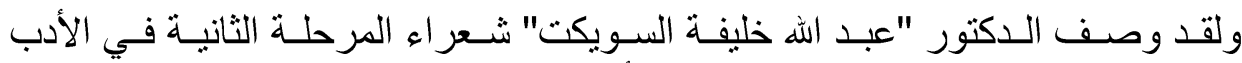

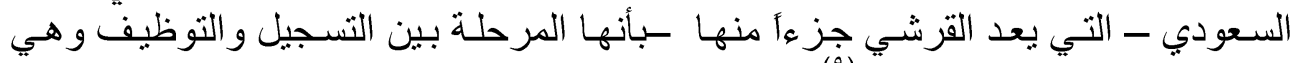

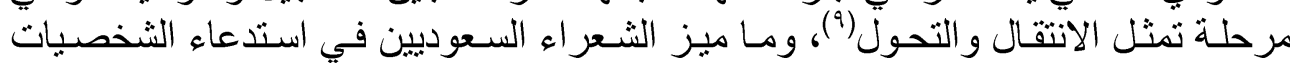

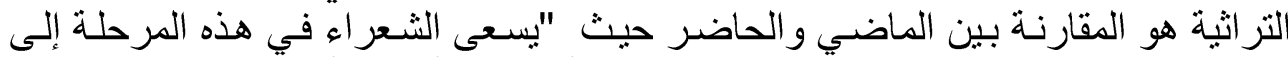

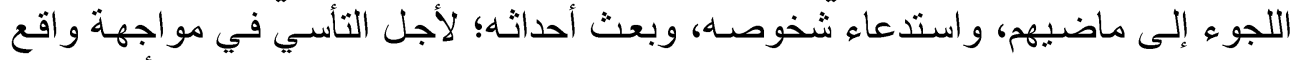

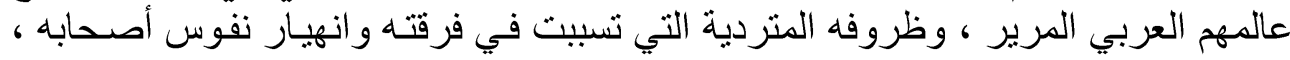




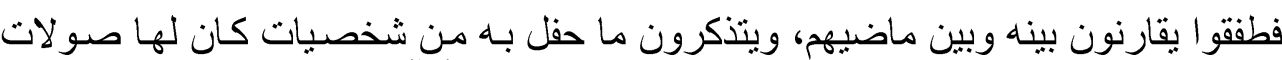

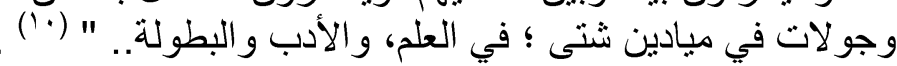

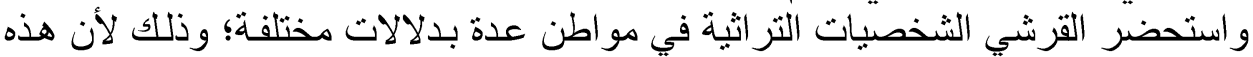

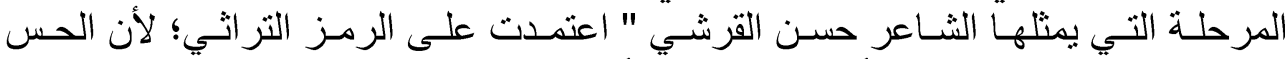

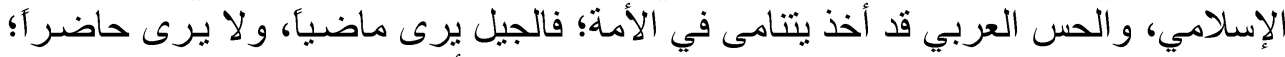

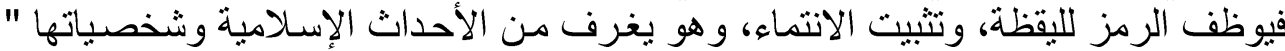

وقد جـاءت المصـادر التر اثبـة المتتوعـة للثخصيات التي استحضـر ها الثـاعر بوصفها

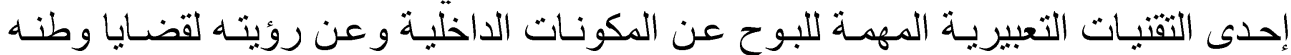
ومجتمعه، وكذلك كانت ر افداً تاريخياً مهمأ لتسجيل الوقائع السياسية و التاريخية و الاجتماعية

$$
\text { في عصره. }
$$

مصادر استداعاء الثخصيات التراثية:

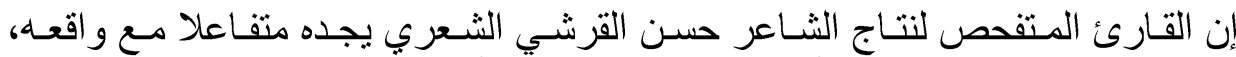

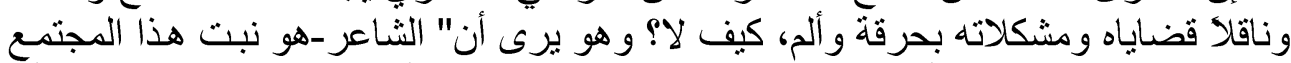

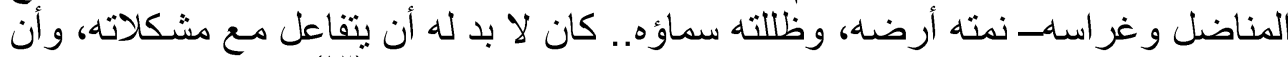

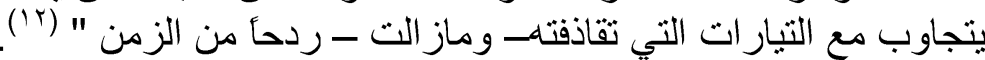

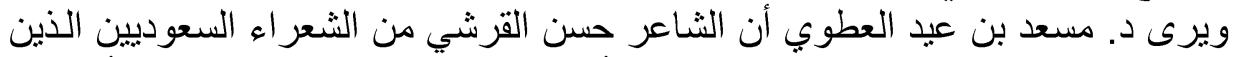

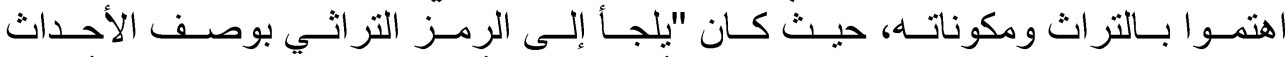

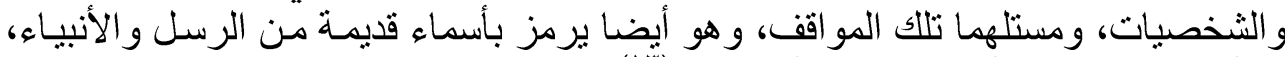

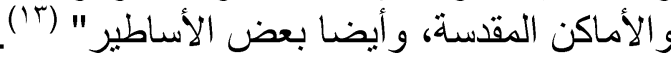

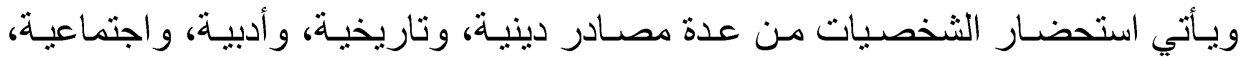

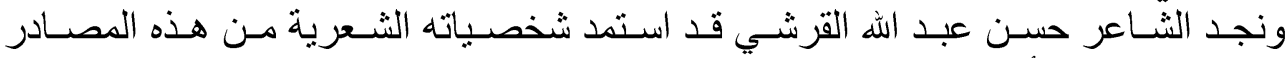
المختلفة، ويمكننا أن نجمل المصادر التي استدعى " القرشي " منها الثخصيات في قصـائده

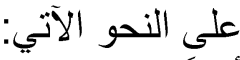

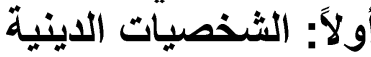

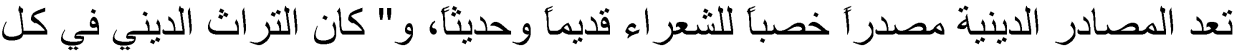

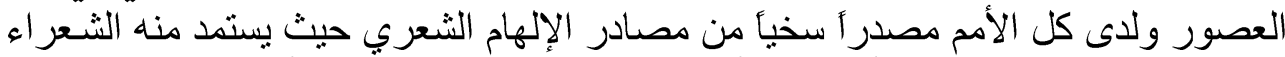

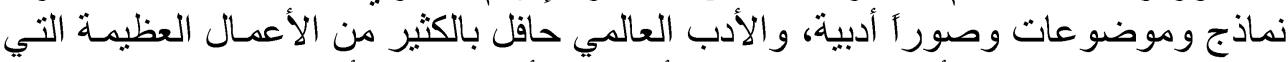

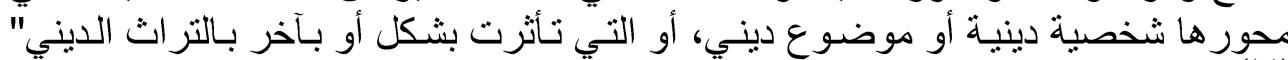

ولا شك أن القرآن الكريم هو أهم المصادر الدينية على الإطلاق، " وقد اعتمد الثـاعر

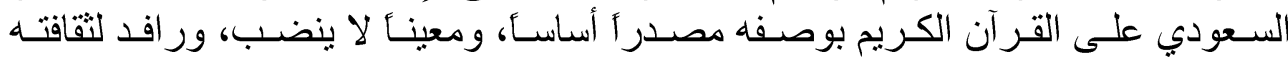

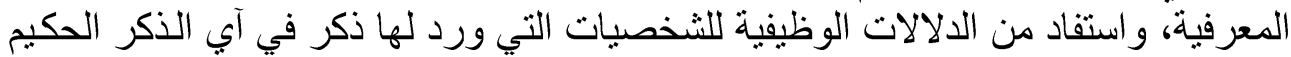

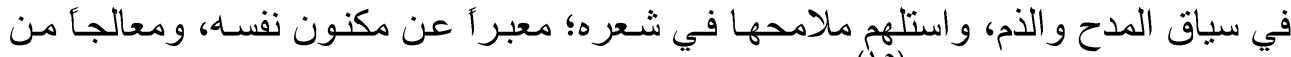
خلالها قضاياه المعاصرة المده " (10).

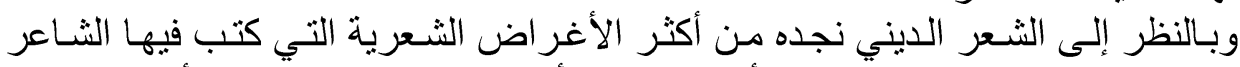

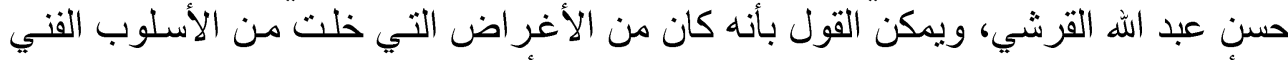

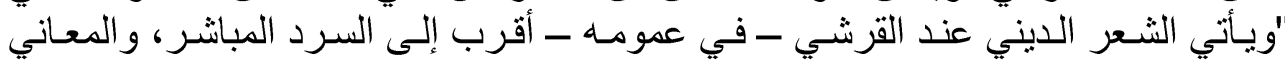

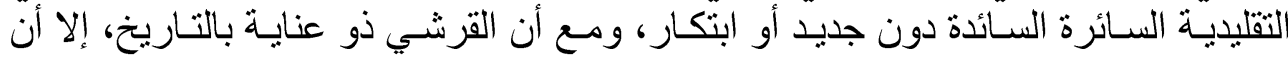


شعره الديني ليس غنيا بالنبض التاريخي، ومـا يورده لا ليعدو أن يكون حقائق عاديـة خاليـة

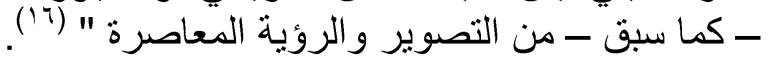

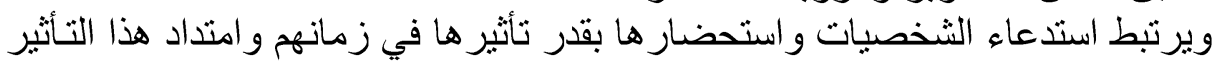

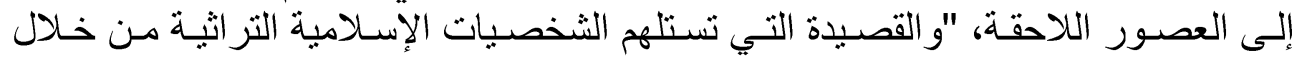

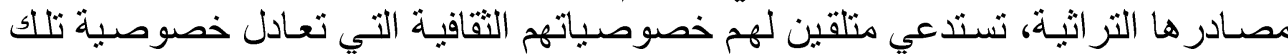

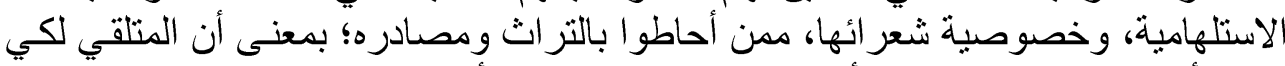

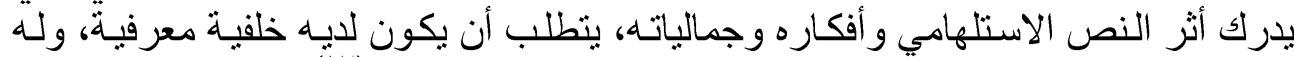

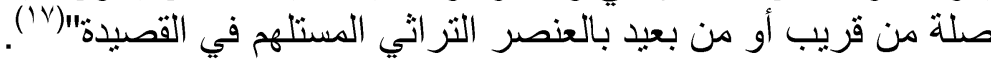

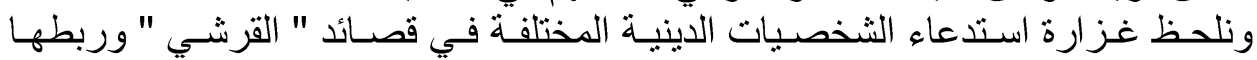

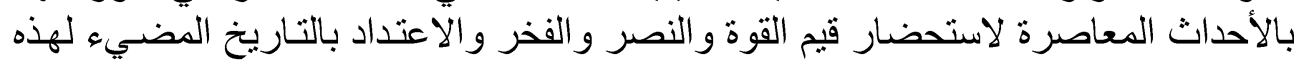

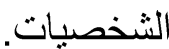

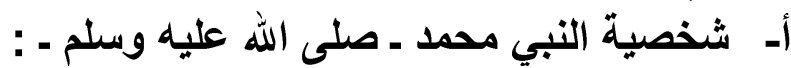

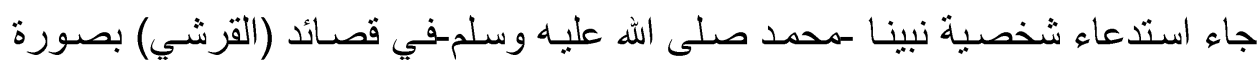

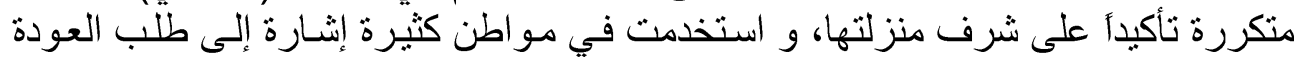

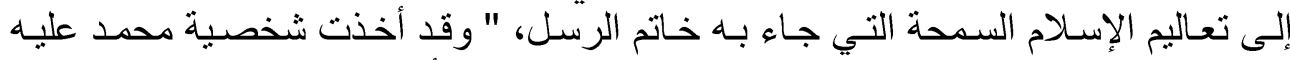

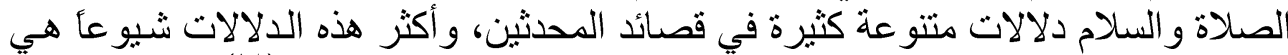

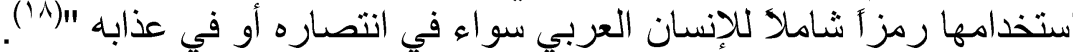

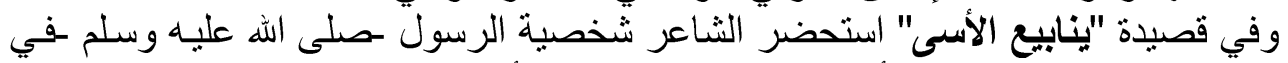
معرض حديثه عن الإسلام و أمجاد المسلمين التي يرى أن مجتمعه ابتعد عنها، فقال:

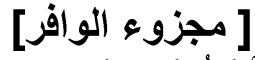

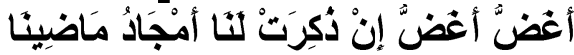

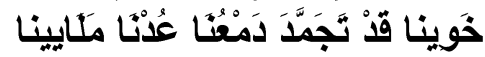

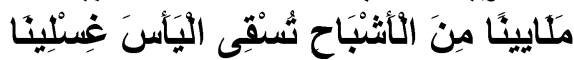

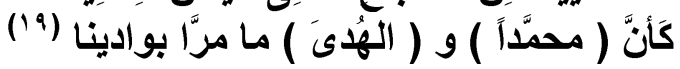

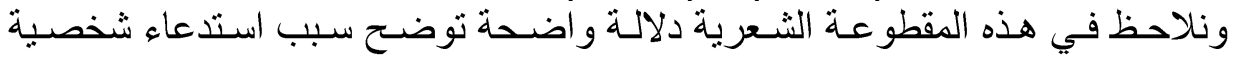

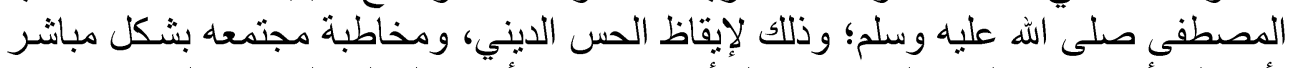

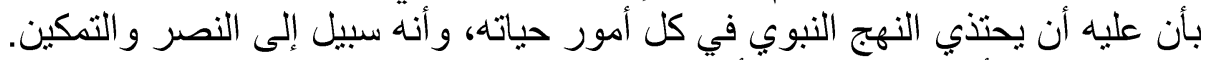
وفي قصيدة أخرى يبعث فيها أثو اقه وحنينه إلى "مكة " مستحضر الشخ الثصية الرسول صلى الله عليه وسلم-في ثنايا هذا الشوق، فقال:

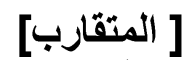

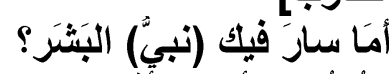

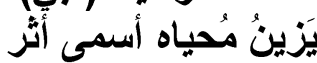

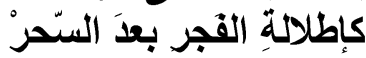

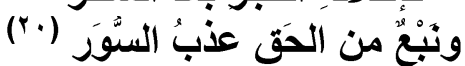

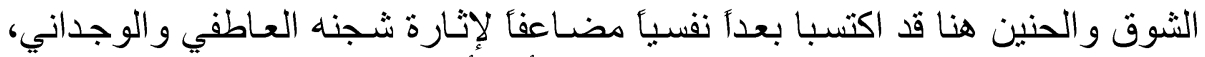

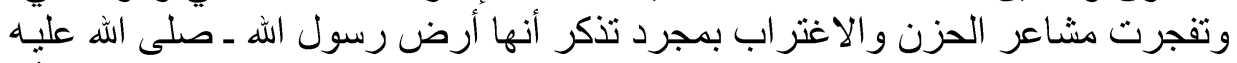

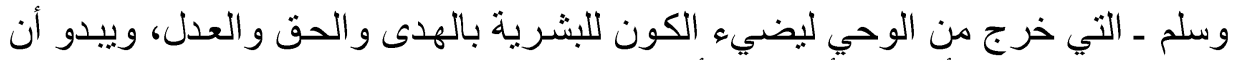

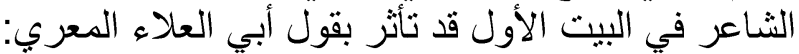

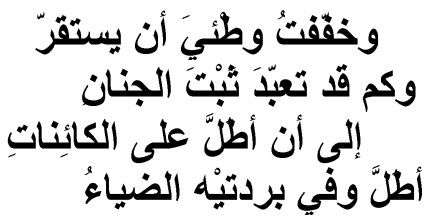

\section{] [ الخفيف ]}




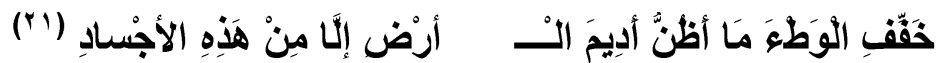

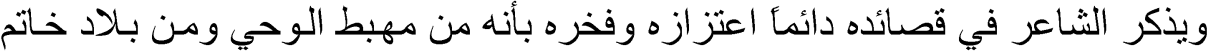

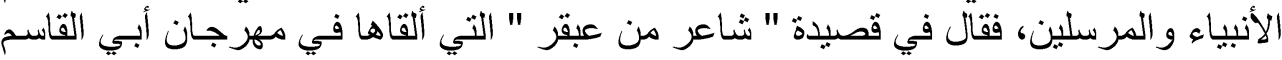

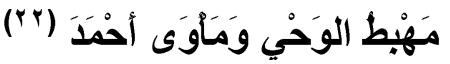

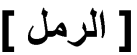

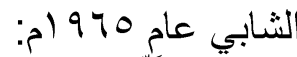

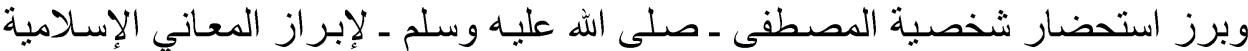

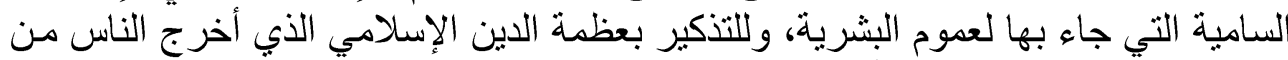

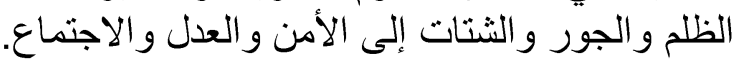
ب - شخصيات الصحابة والتابعين

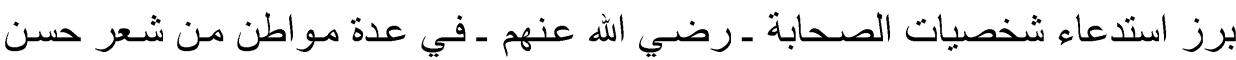

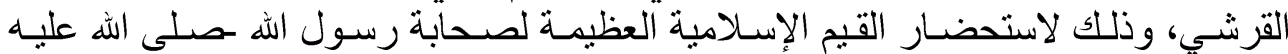

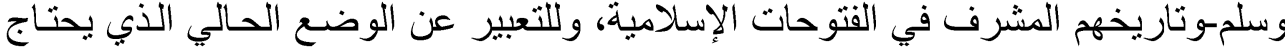

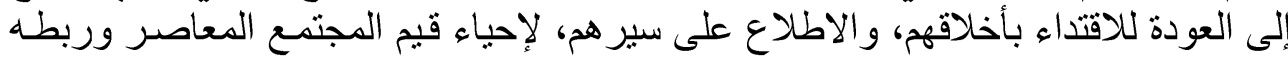
بالماضي الإسلامي المشرق.

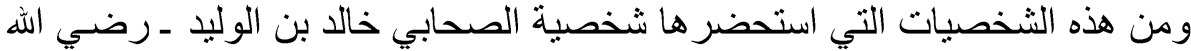

\section{[ [الخفيف]} عنه - وتكرر ذللك في أكثر من قصيدة لإبراز قيم الثجاعة و البطولة، ومن ذلك قوله:

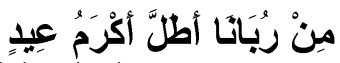

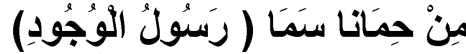

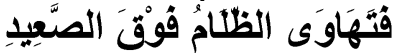

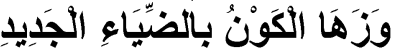

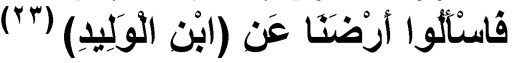

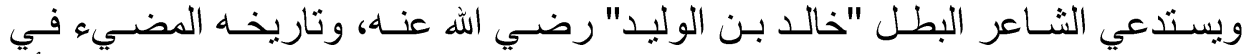

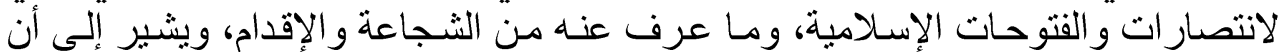

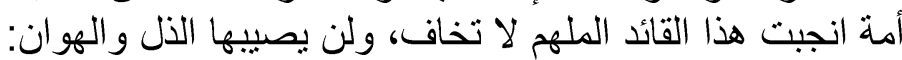

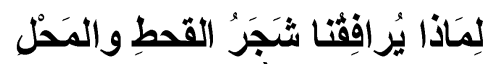

[المتقارب[ ]

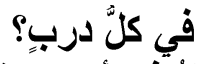

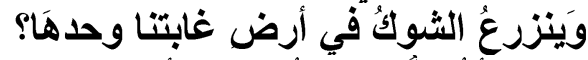

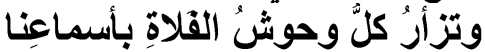

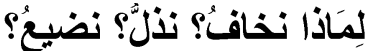

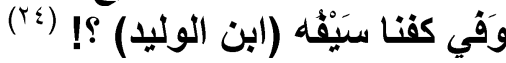

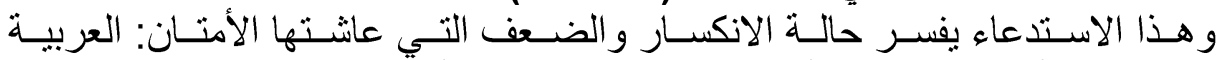

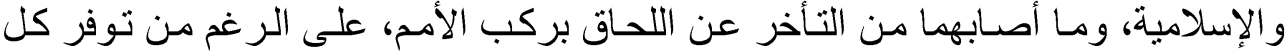

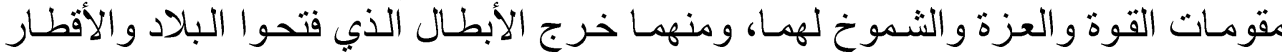
وفي قصـبدة "فيم جئنـا؟" التي ألقاهـا في مهرجـان الثـعر الحـادي عشـر بتونس عـام

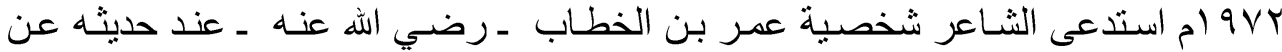

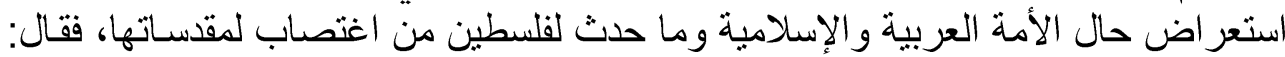




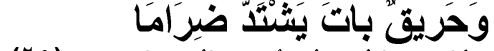

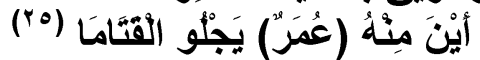

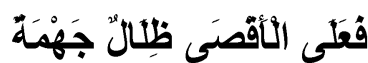

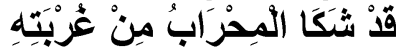

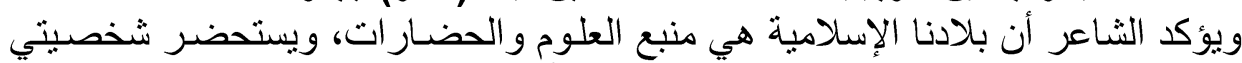

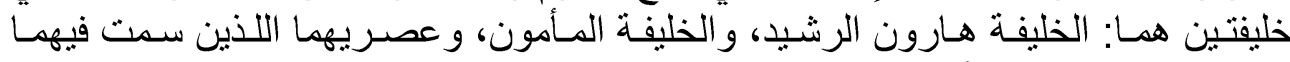
العلوم وارتقت فيهما الآداب و الفنون الإسلامية:

\section{أرضُنا للاعُلوم للتّجدِيدا

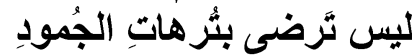

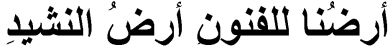

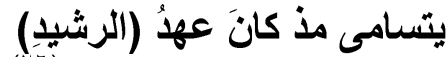

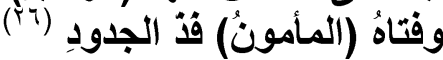

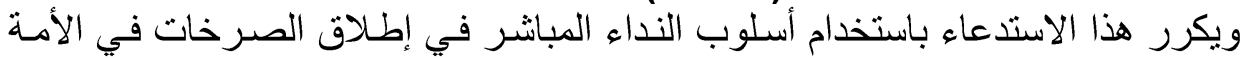

[ الخفيف

$$
\text { [المنقارب] }
$$$$
\text { العربية والإسلامية لاستتهاض الهمه، وتذكر الأمجاد الإسلامية: }
$$

$$
\begin{aligned}
& \text { أين أبناءُ (مثنّاي) القتى؟ } \\
& \text { و (ابن الوَليّا)؟ } \\
& \text { أين (نورُ الاين)؟ } \\
& \text { في الوادِي السعيدِ } \\
& \text { و (صلاحُ الدين)؟ } \\
& \text { راية التصنز ألتعتيد (rV) }
\end{aligned}
$$

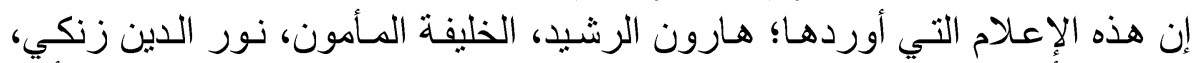

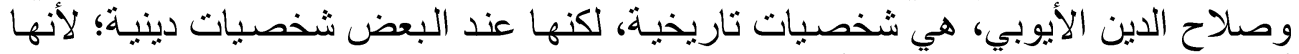

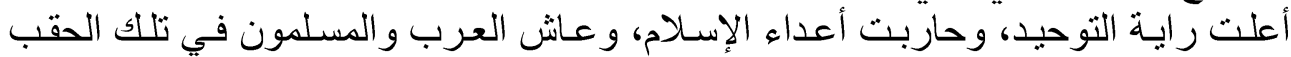

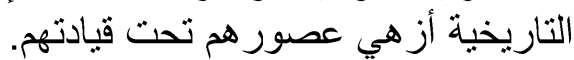

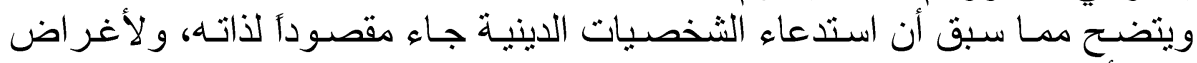

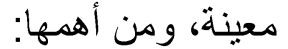

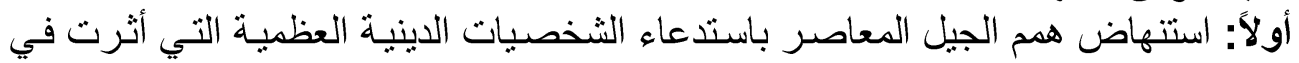

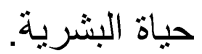
ثانياً: دعم تجربته الثعرية المفعمة بروح العصر من خلال هذه الاستدعاءات المتو الية لهذه الشخصبات البطولية.

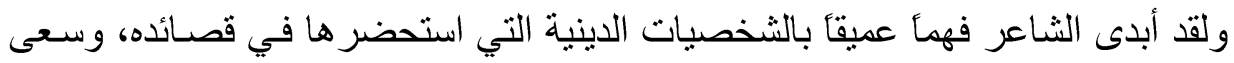

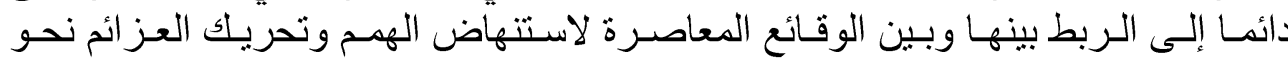

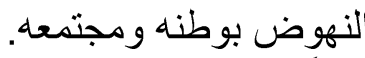
ثانياً: الشخصيات التاريخية

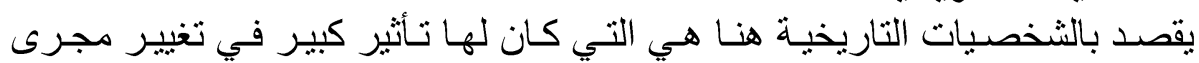

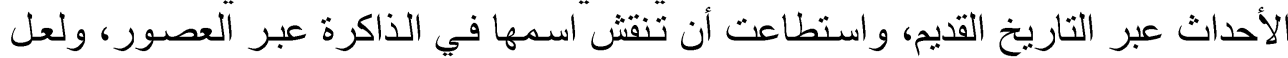

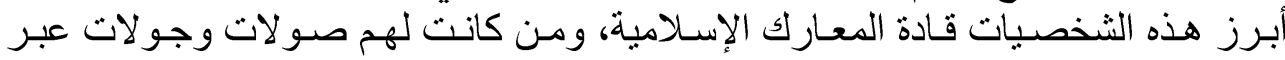
القرون الماضية. 


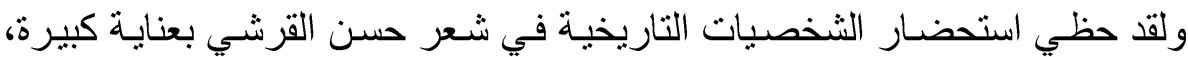

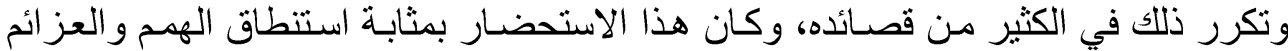

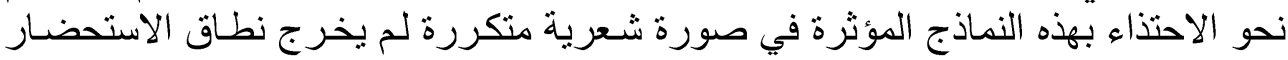

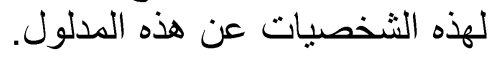

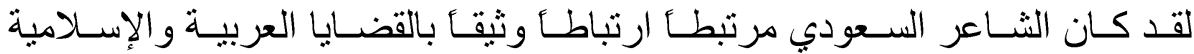

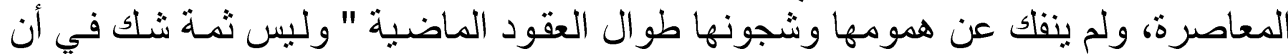

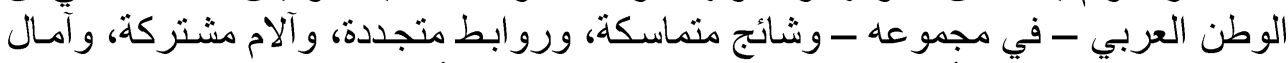

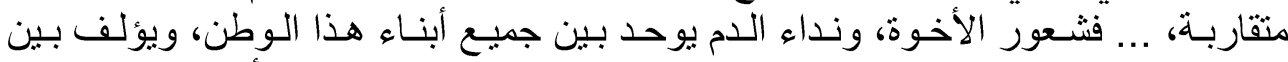

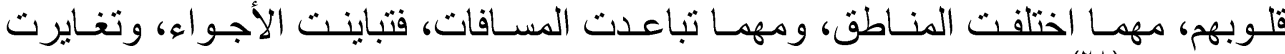

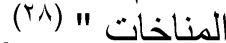

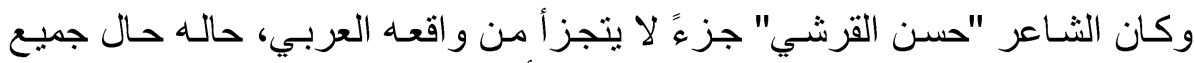

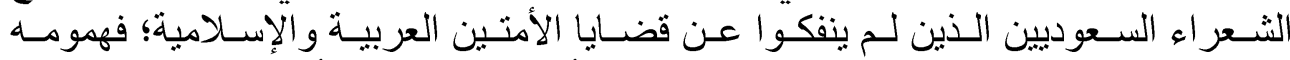
ومشكلاته وقضايا تلامس وجدانهم، وفي قصيدة " أنـا العربي" التي ألقاهـا بمناسبة محاولة التة

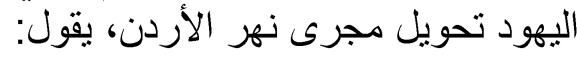

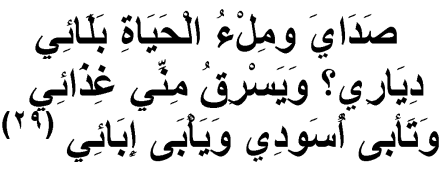

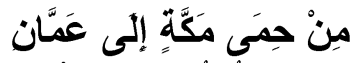

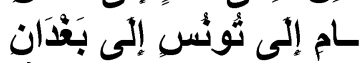

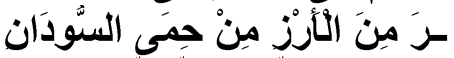

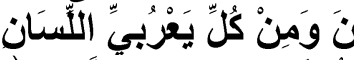

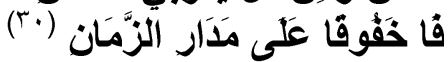

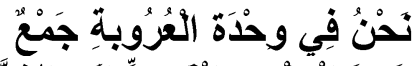

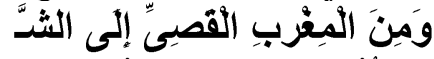

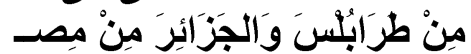

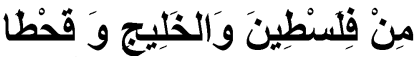

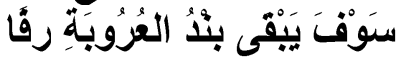

[الخفيفة

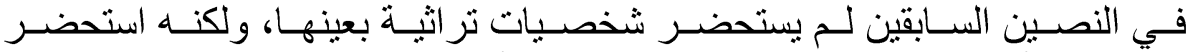

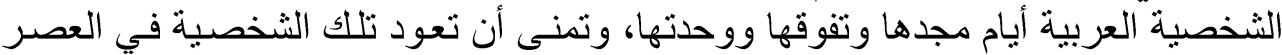

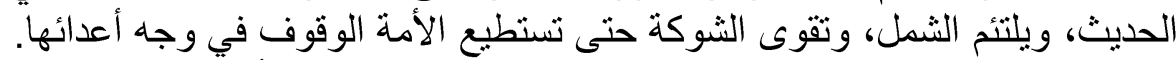

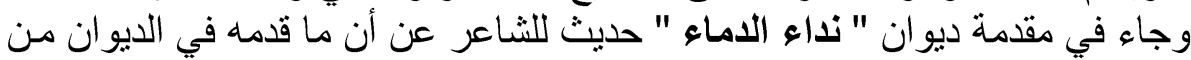

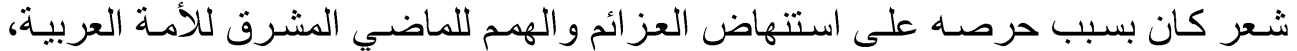

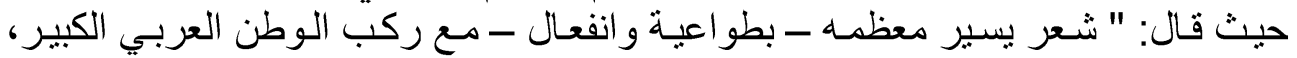

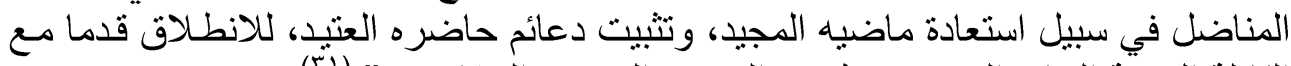

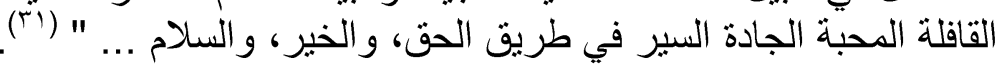

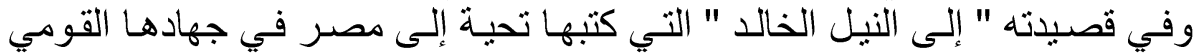

العتيد، ويستدعي شخصياتها، وحضارتها القديمة:

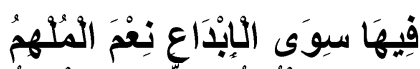

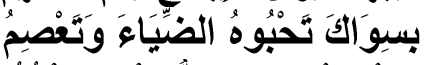

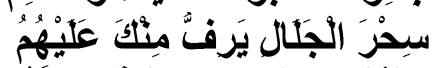

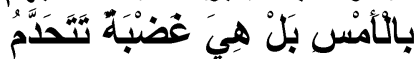

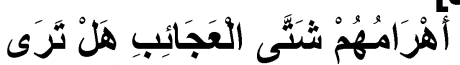

[الكامل

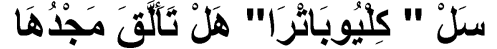

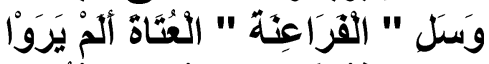

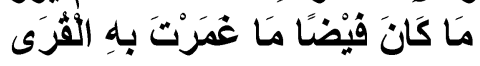




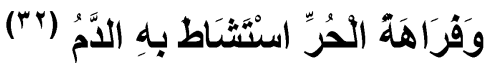

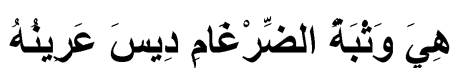

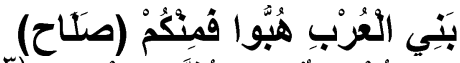

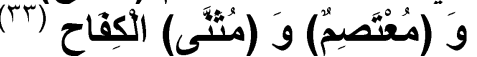

[المتقاربة

وفي قصيدة "ثوار الجز ائر" التي نظمها القرشي بمناسبة ما قام به أحمد بن بيلا ومـا

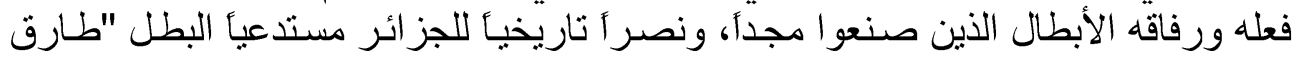
بن زياد "، وو الي الأندلس السمح بن مالن مالك الخو لاني؛ فقال:

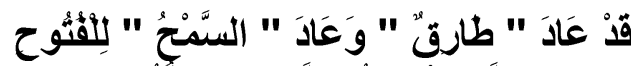

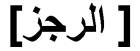

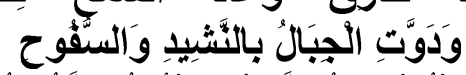

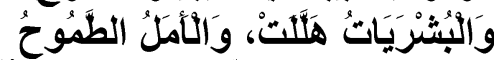

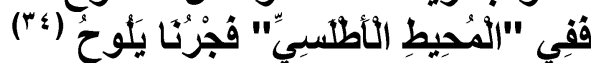

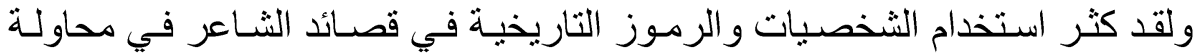

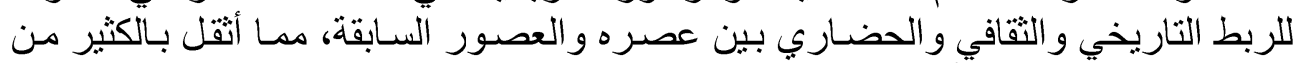

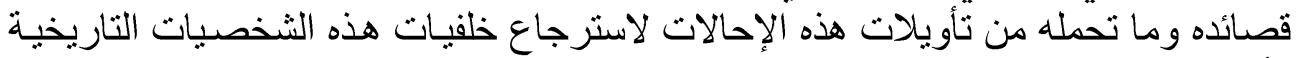

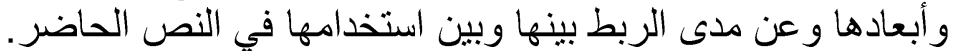

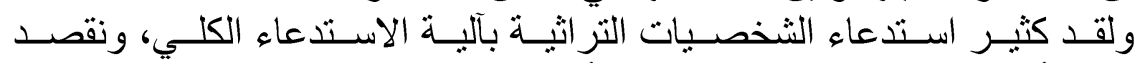

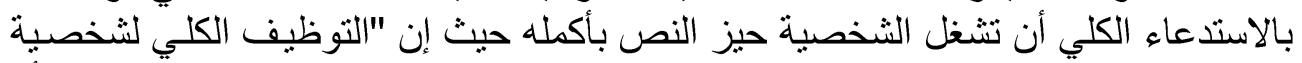

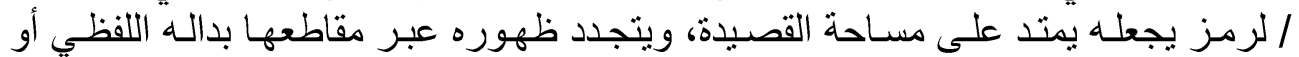
بدلالته الإيحائية، فهو يعمل بطريقة ما على تماسك وحدتها، وكلية ولية بنيتها، ويمثل البؤرة التي

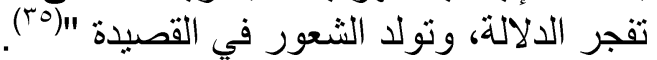

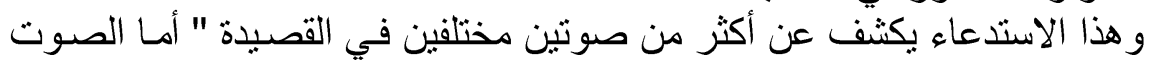

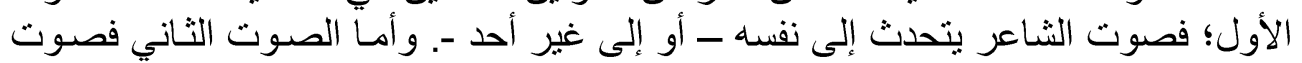

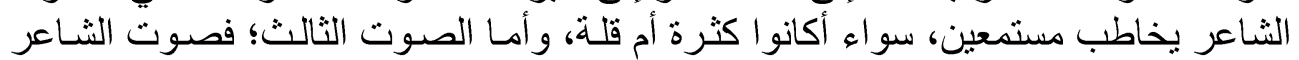

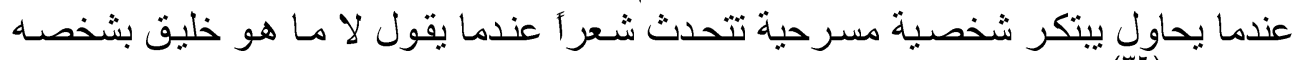

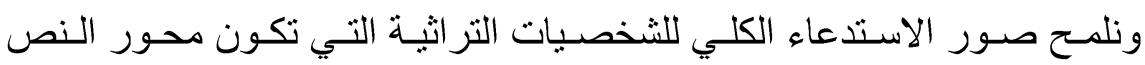

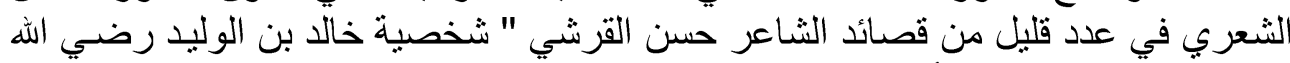
عنه "و" صَلاح الدين الأيوبي" حيث شكلتا محور بناء للكثير من قصائده.

ثناثثا: الثخصيات اللغوية والأدبية

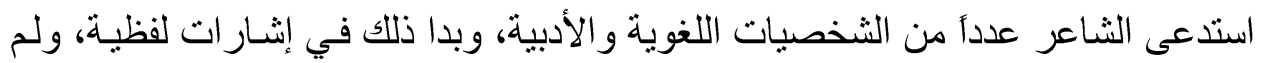
تكن هذه الثخصيات محور ألصائده، وقد جاءت هذه لإضفاء داء دلالات جديدة تنم عن وعيـه

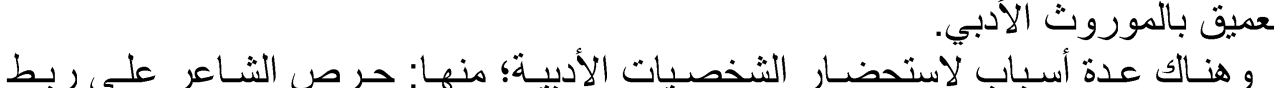

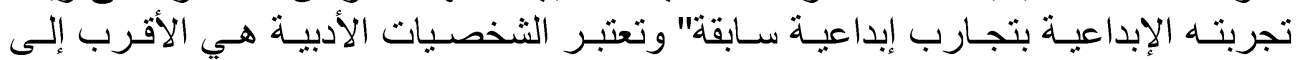

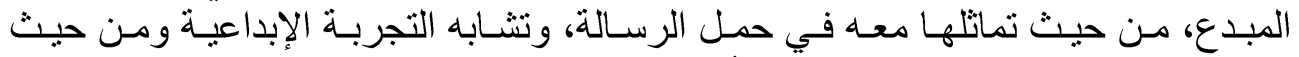

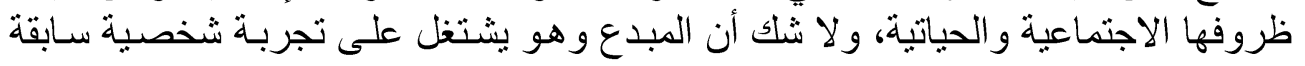


أن ينتقي منها، ويخا، ويختار مـا يتواءم مـع تجربته مـن جهة، ويبحث فيها عن ذاتـه من جهة

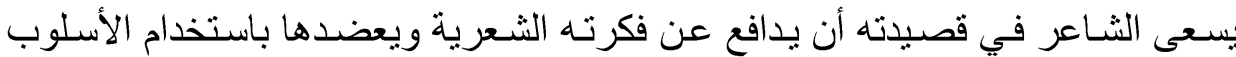

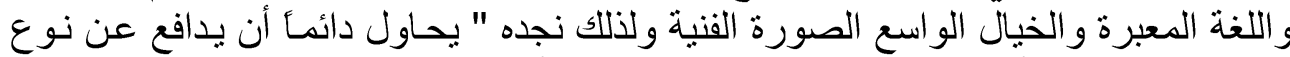

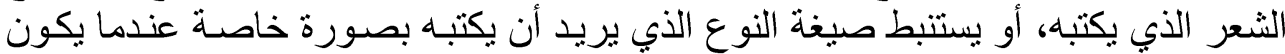

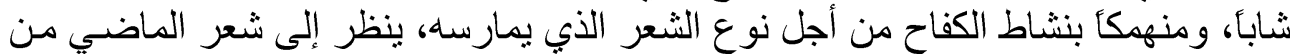

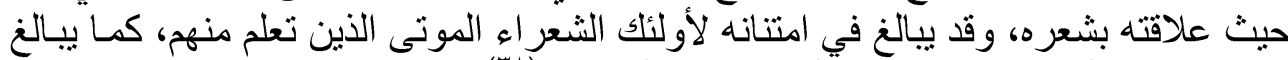

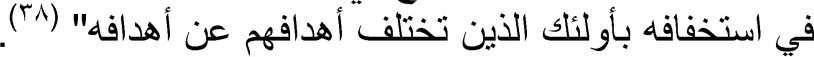

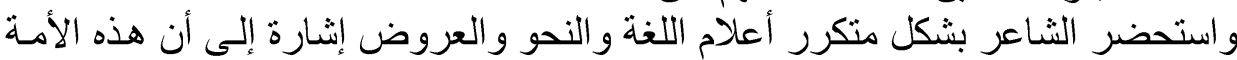

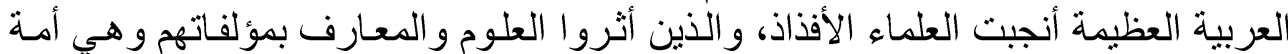
متجددة متطورة. ومن ذلك قصيدته التي ألقاها في ذكرى مجمع اللغة العربية في عيده الخمسين، استدعى فيها

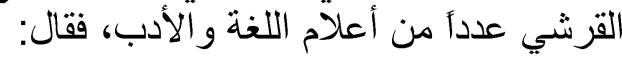

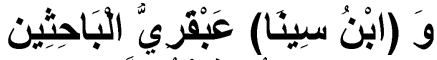

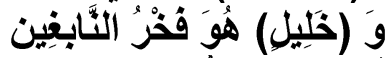

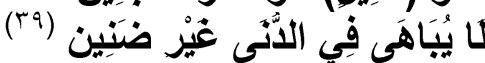

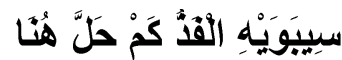

[الرمل]

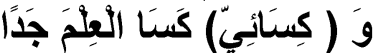

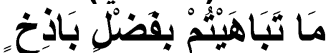

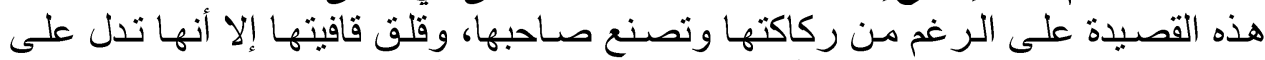

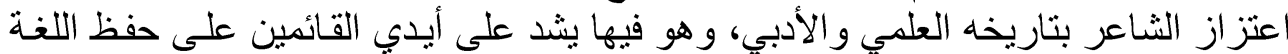

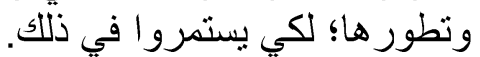

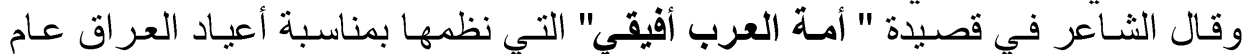

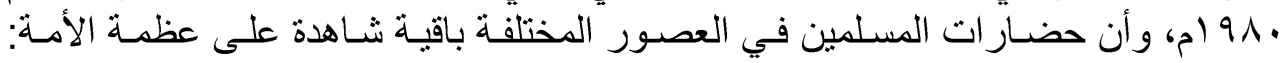

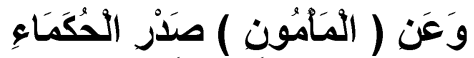

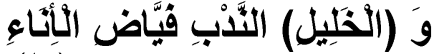

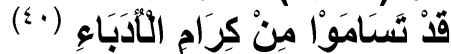

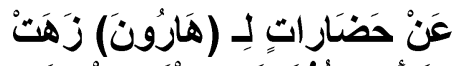

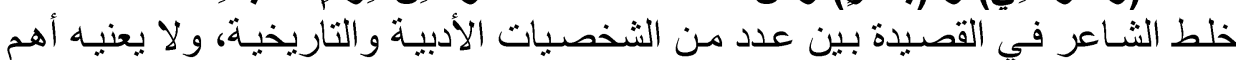

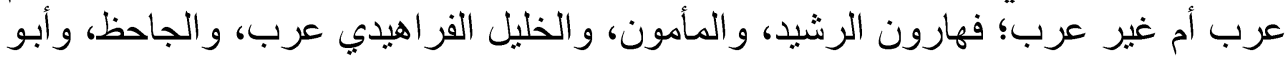

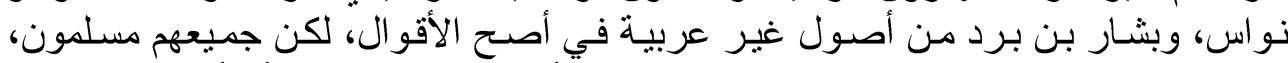
وذكره هذا الخليط من الجنسيات يناسب المكان التي ألقيت فيه القصيدة؛ لأن أهل العز العراق من أعن

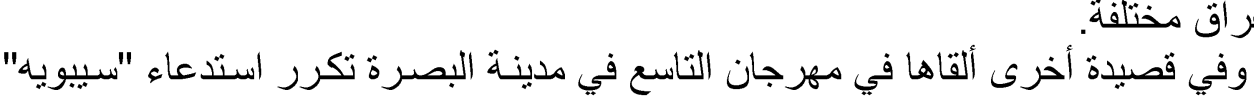

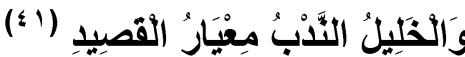

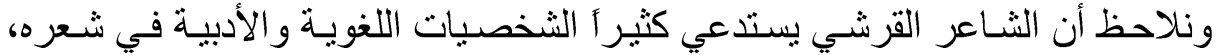

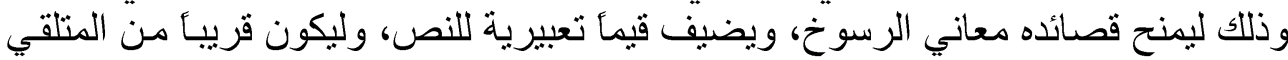

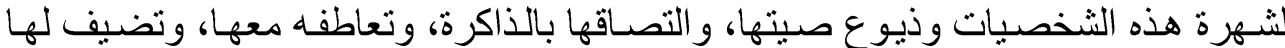
معاني ودلالات جديدة بما تحمله هذه الثخصيات الثَات المستدعاة.

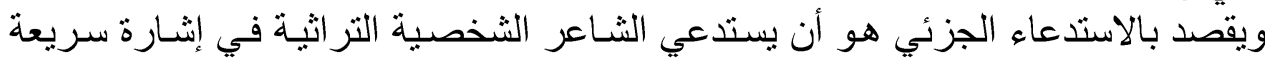

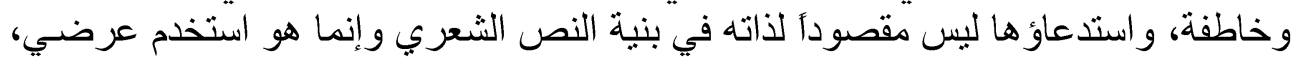




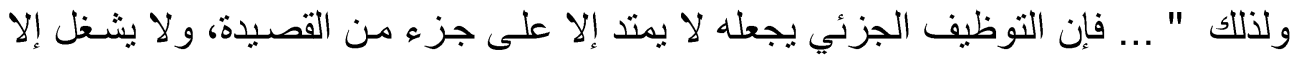

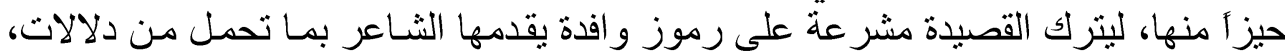

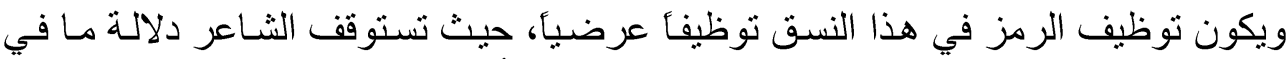

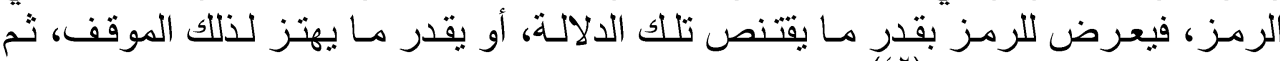

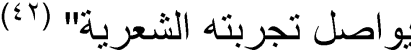
و ون ذلك ما جاء في قصيدة " كفاح فلسطين" من استدعاء جزئي لعدد من الثخصيات

التاريخية البطولية: - ت البعاء

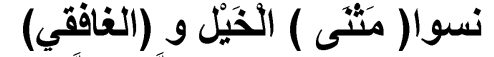

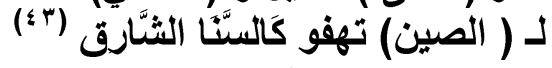

لقد نَسُوا ملاحم (ابن الوليد)

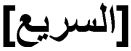

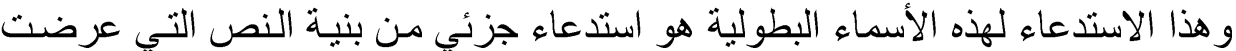

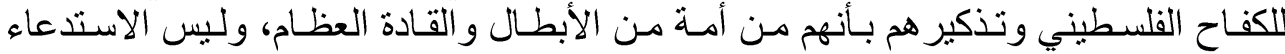
مشكلا للبنية الشعرية للقصبدة. إلى أن وصل في قوله:

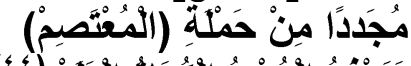

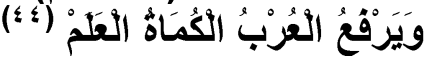

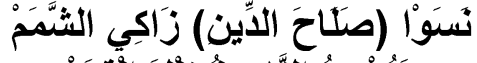

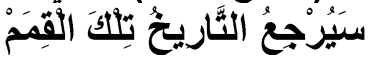

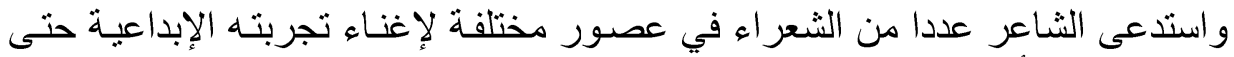

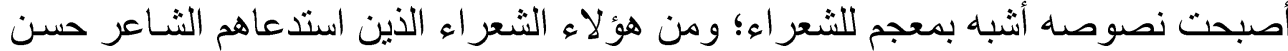

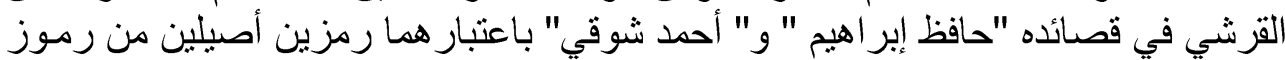

\section{[ [ [ الخفيف [ ]}

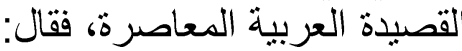

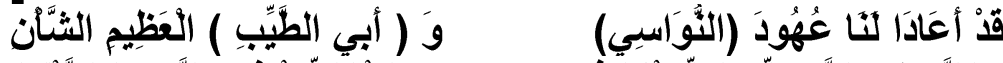

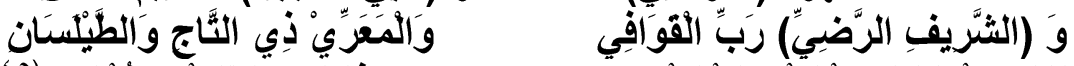

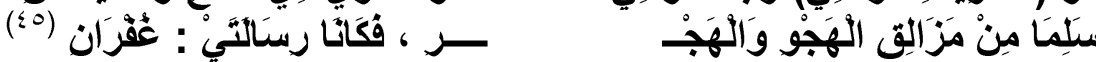

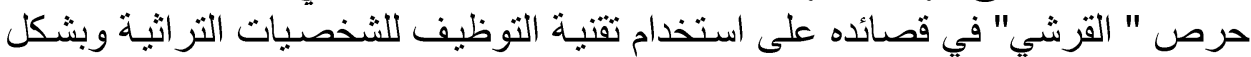

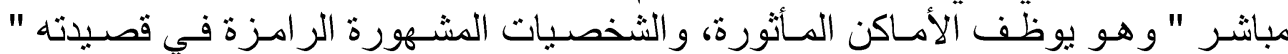

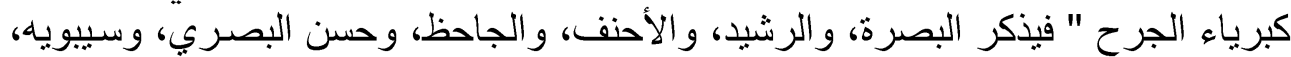

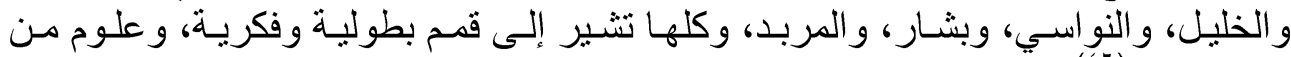

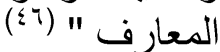

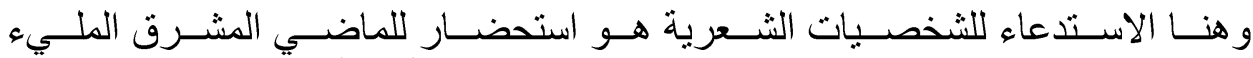

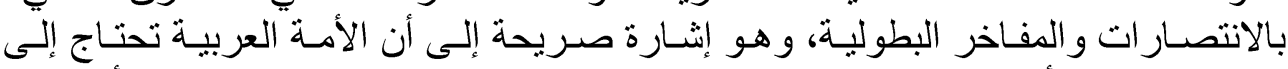
نمـاذج وقدو ات أمثنال هذه الشخصيات العظيمـة لاستتهاض همتهـا لكي تسـتعيد أمجادهـا السالفة ويستدعي الثـاعر أمير الثـعر اء " أحمد شـوقي" في معرض بالإبـداع الثـعري لثـعر اء

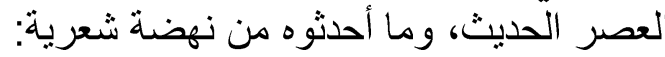

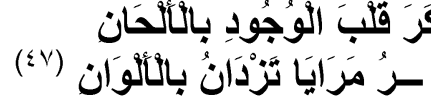

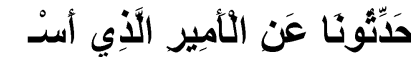

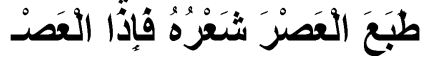




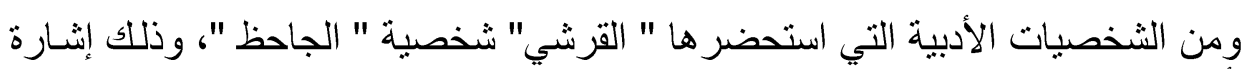
إلى أن السعوديين لديهم الثقافة العالية وعلى قدر كبير من الفصاحة و البلاغة و البيان:

\section{[الخفيف]}

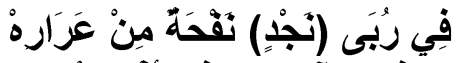

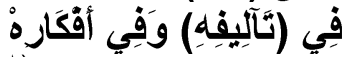

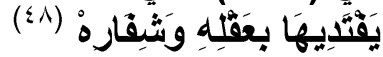

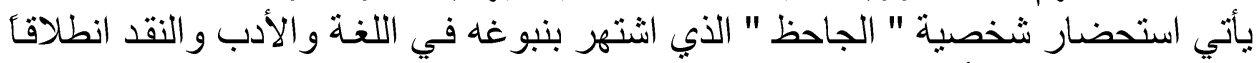
لاستحضار شخصيات أدبية كثيرة بشكل مباثشر لربط الحاضر بالماضي، و ولا تظهر في هذه

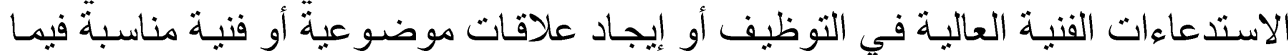

بينها.

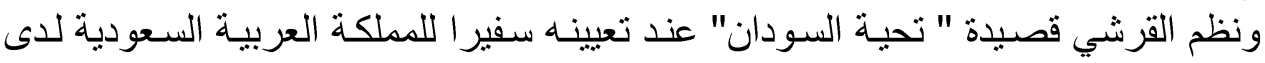
جمهورية السودان، وخاطب السودانيين بمشاعر وجدانية مليئة بالإيحاءات و الدالالات، فقال: [الخفيف]

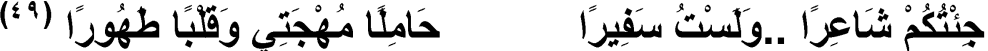

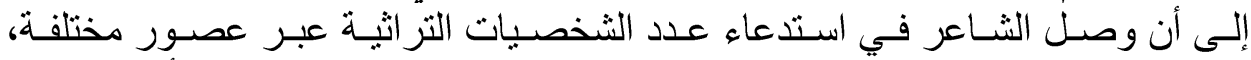

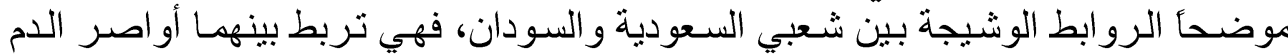
و النسب و العقيدة و المصبر ، فقال:

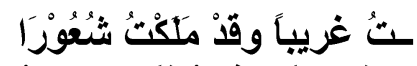

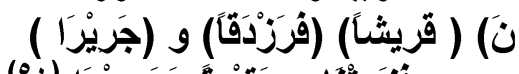

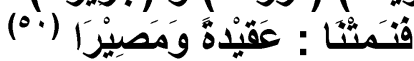

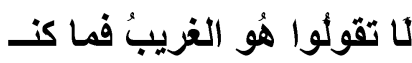

[الخفيف]

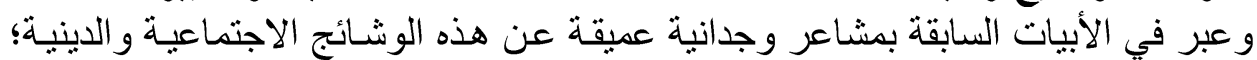

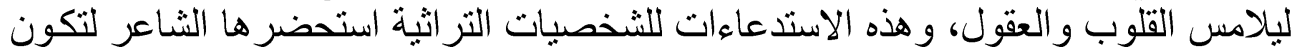

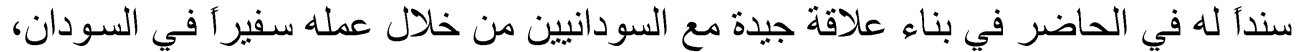

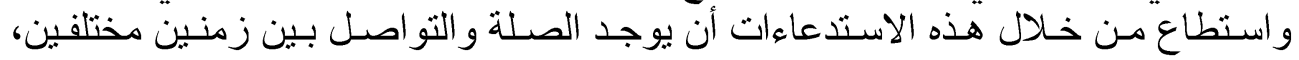

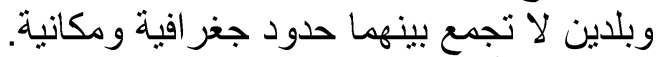

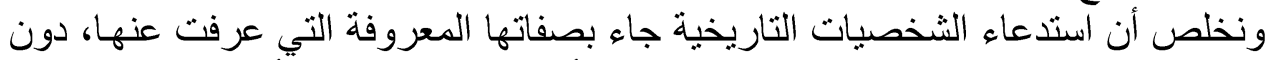

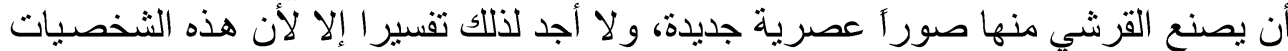

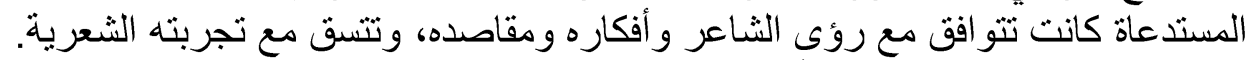

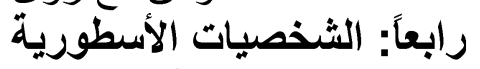

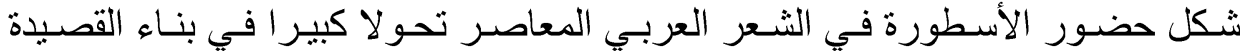

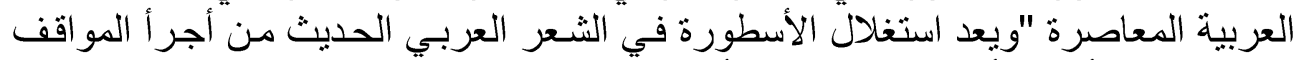

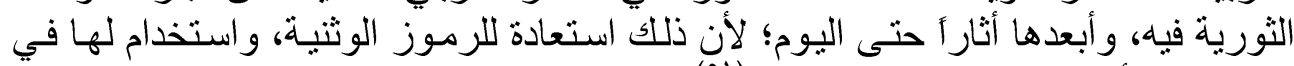

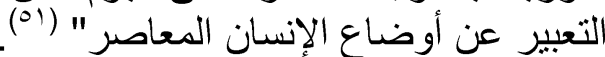

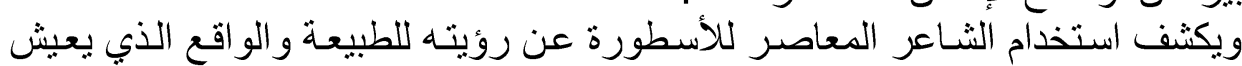

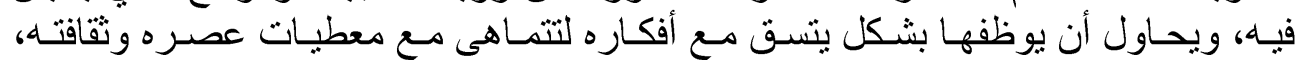

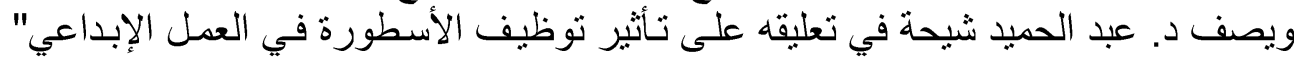

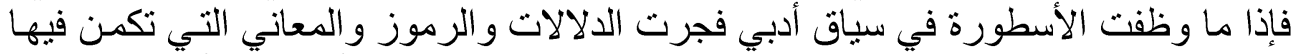

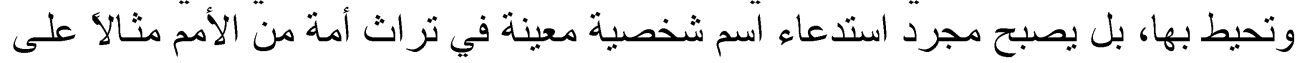




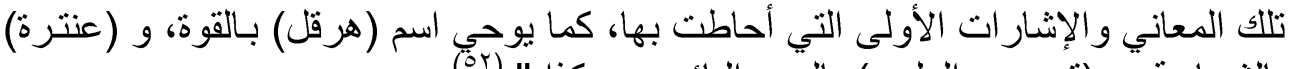

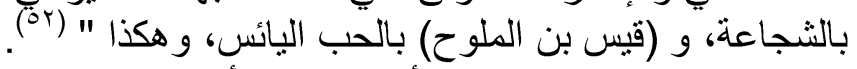

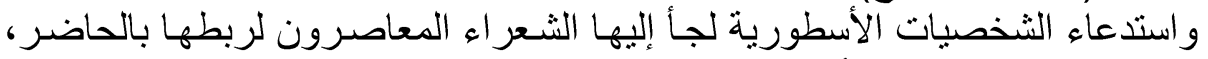

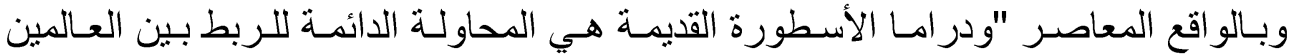

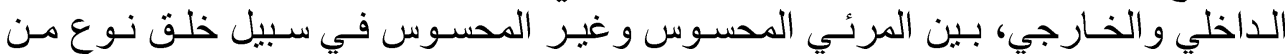

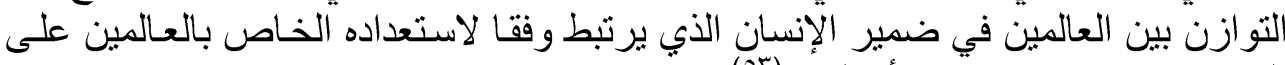

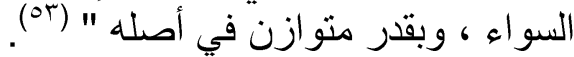

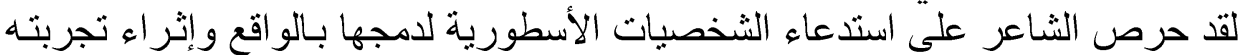

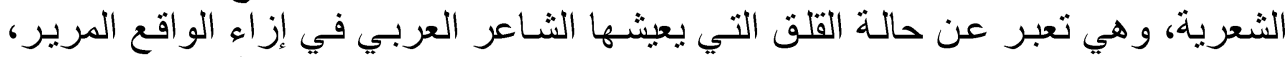

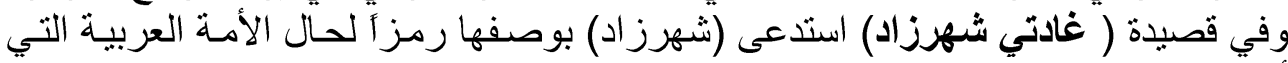

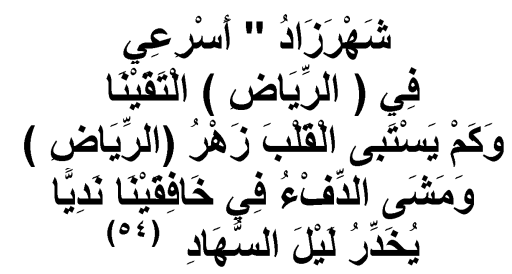

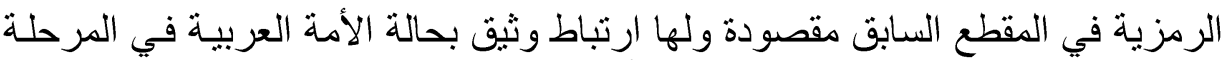

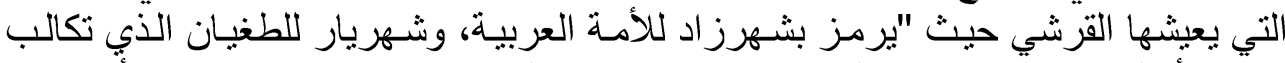

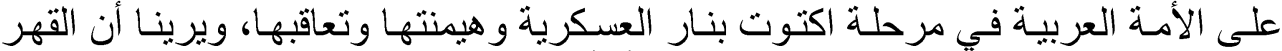

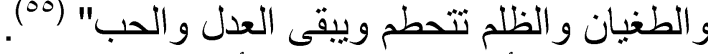

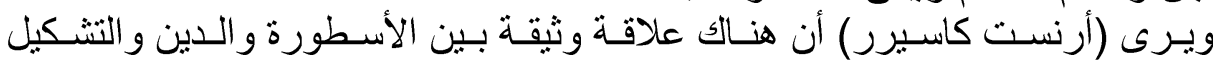

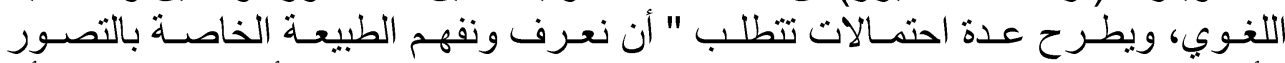

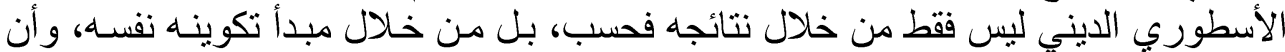

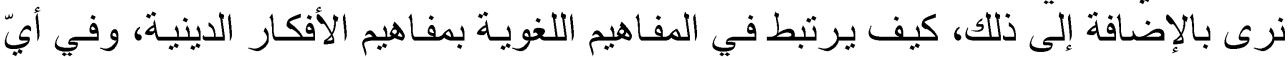

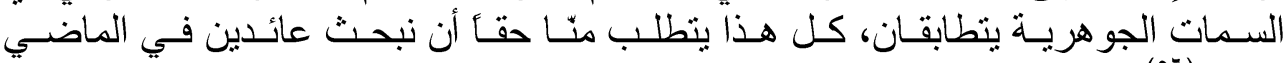

وفي قصبدة "بيروت في قبضـة الظلام " استدعى الثـاعر شخصية "اللدراكولا" الخياليـة

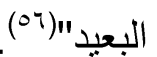

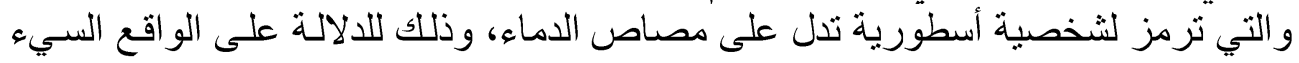

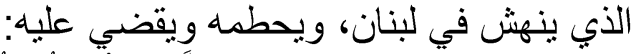

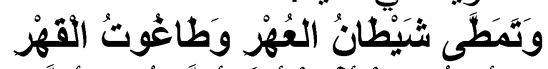

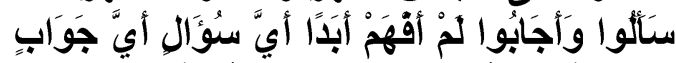

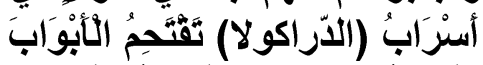

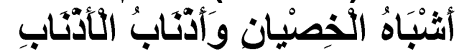

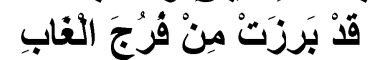

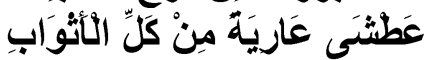

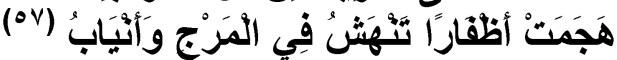

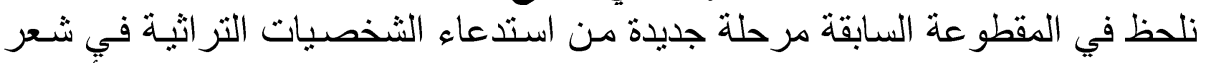

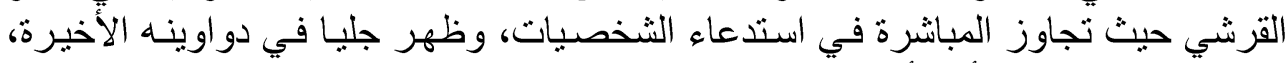

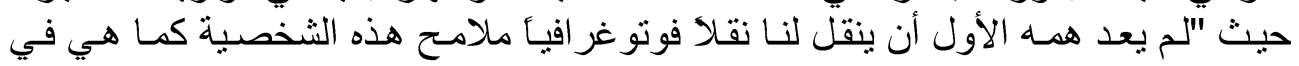




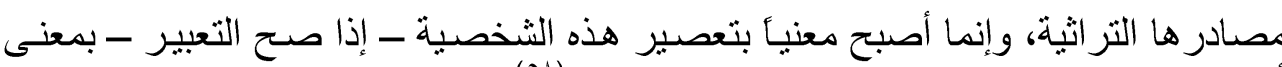

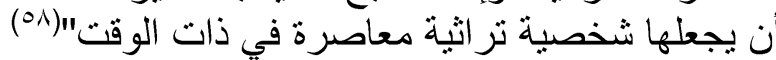

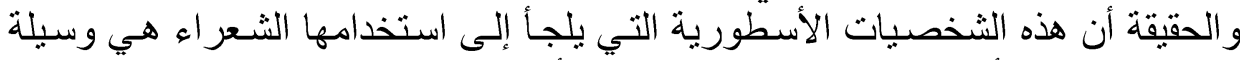

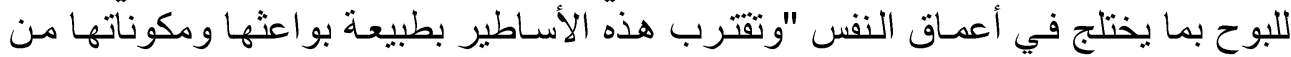

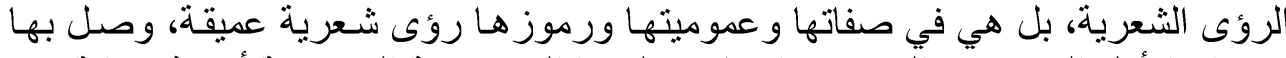

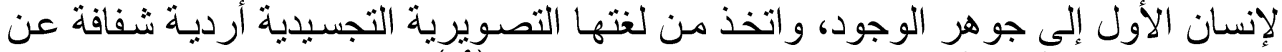

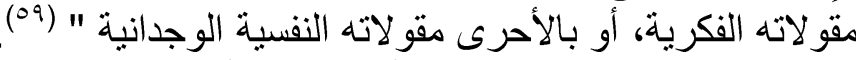

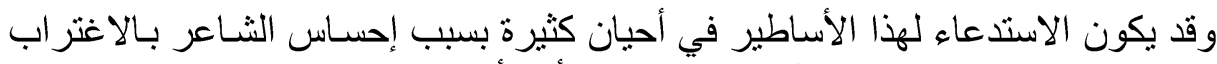

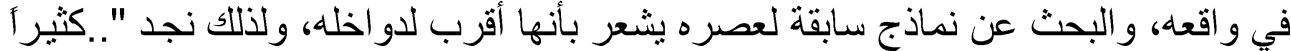

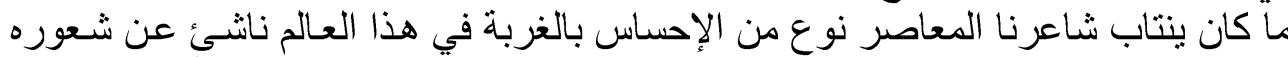

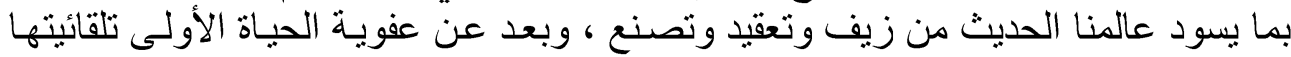

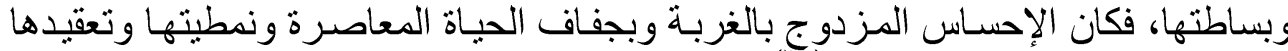

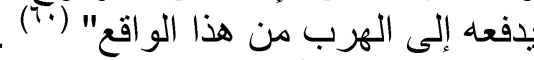

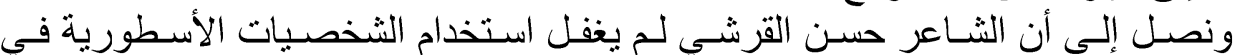

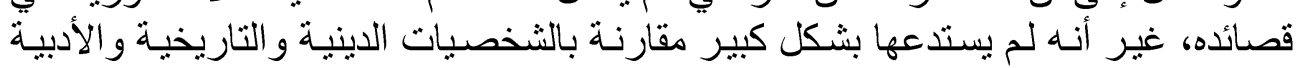

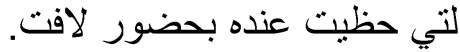




\section{الخاتمة}

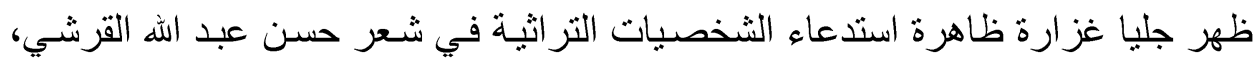

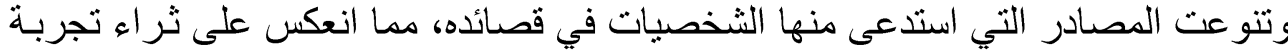

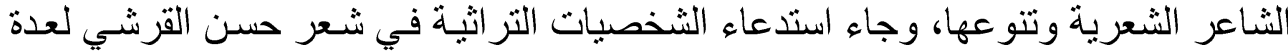

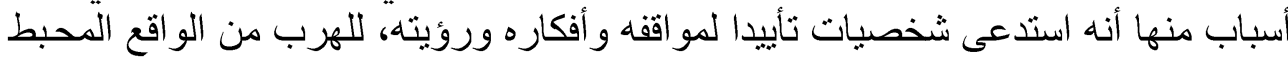

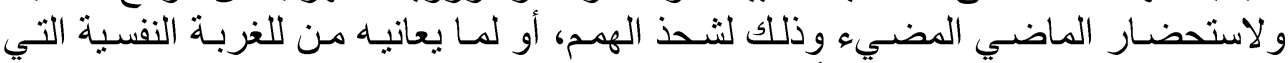
يشعر بها الثناعر تجاه واقعه في أحيان كثيرة.

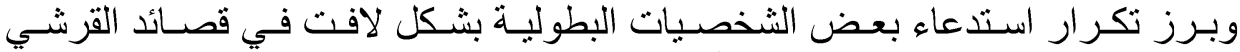

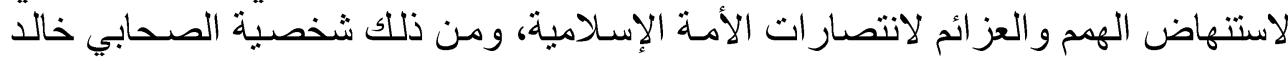

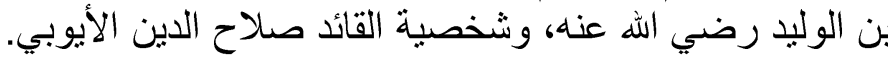

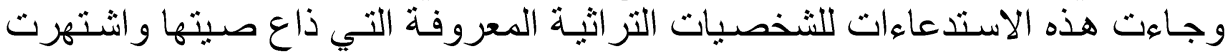

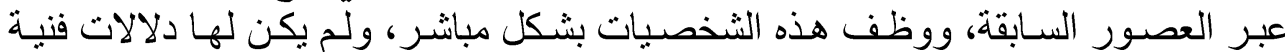

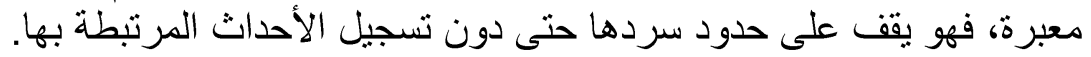




\section{Abstract \\ Reference to historical personalities in the poetry of Hassan Abdullah Al-Qurashi \\ By Zuhair Hassan Saeed Al-Omari}

The return to heritage and its various sources in contemporary poetry takes different dimensions to indicate the accumulation of knowledge, culture and humanity, and an emphasis on intellectual values, and the close historical connection that binds contemporary man to his historical components, from which he derives his strength and ability to keep pace with his present.

This research seeks to study the phenomenon of recalling heritage personalities in the poetry of Hassan Abdullah Al-Qurashi, as one of the prominent models in contemporary Saudi poetry, and the abundance of its poetic production and its connection with the ancient poetic heritage.

In his discussion, he dealt with images of evoking heritage characters in the poetry of Hassan Abdullah Al-Qurashi, as these images varied between summoning religious figures, historical figures, literary figures, and legendary figures. The research also presents the patterns of recalling heritage figures in both its total and partial types.

key words: summoning, heritage characters, Hassan Al-Qurashi, Saudi poetry

\footnotetext{
الإموامش

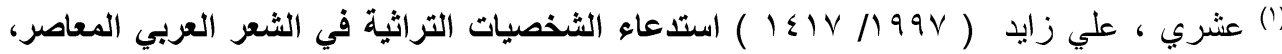

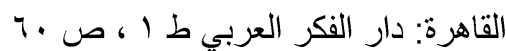

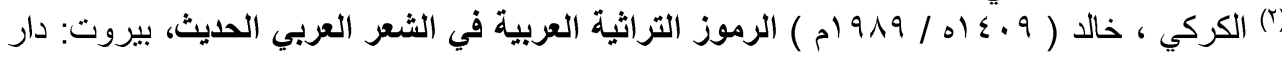

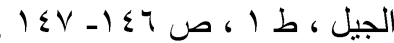

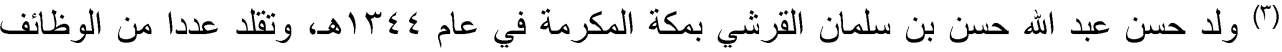

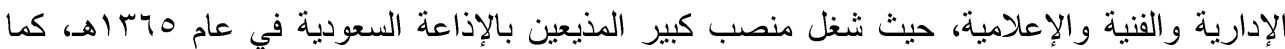

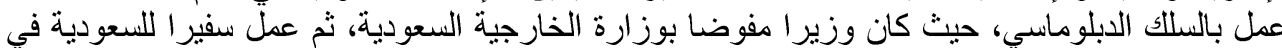

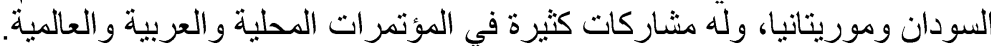

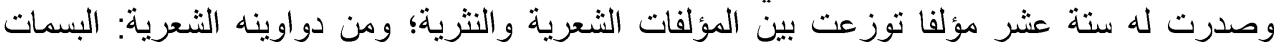

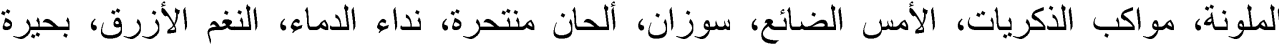

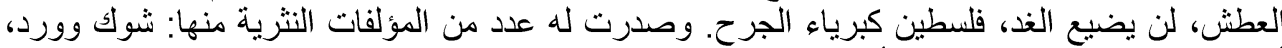
أنات الساقية، فارس بني عبس، ولغ وأنا و الناس.

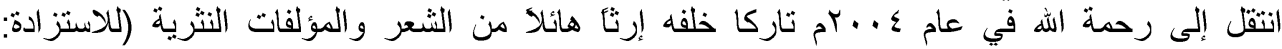

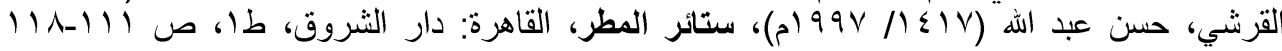

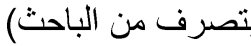

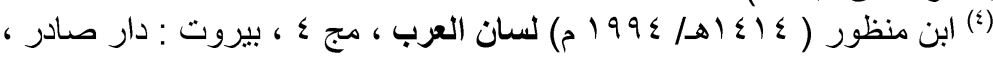

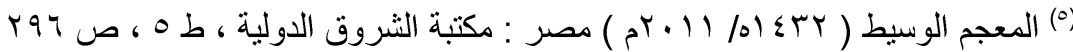

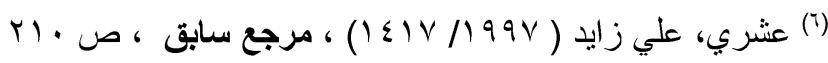

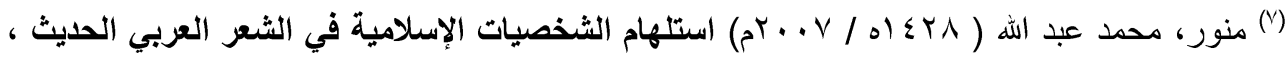

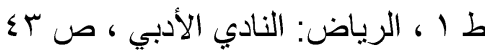




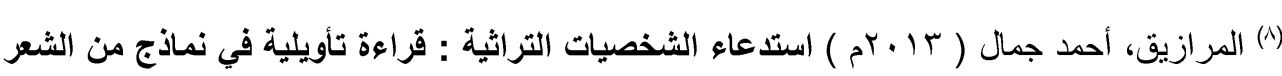

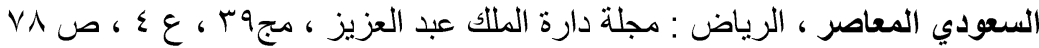

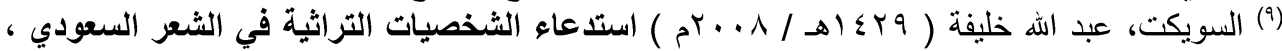

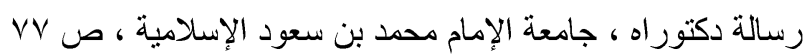

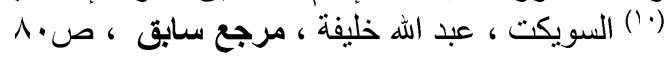

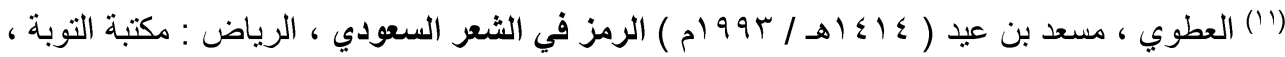

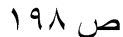

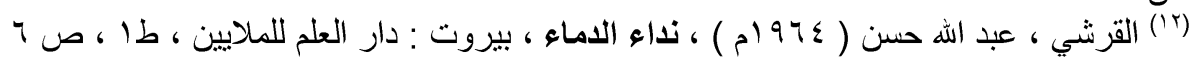

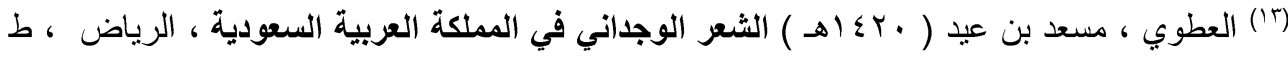
oro

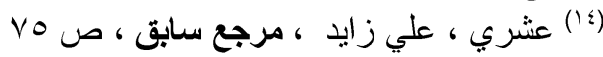

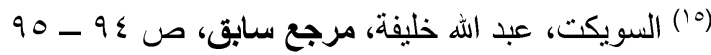

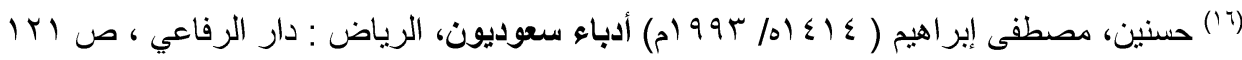

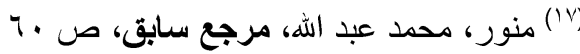

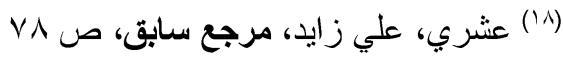

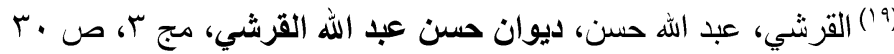

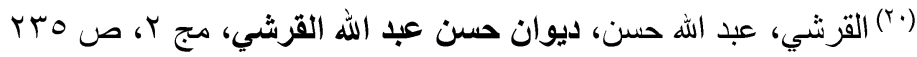

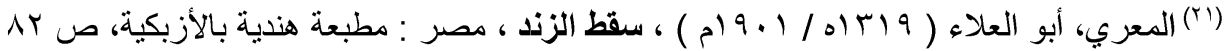

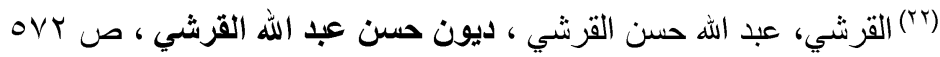

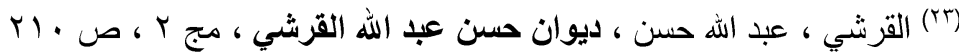

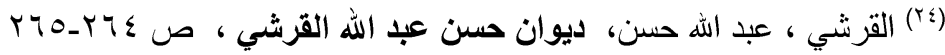

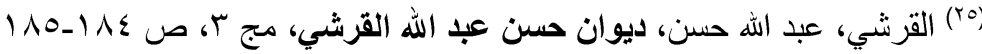

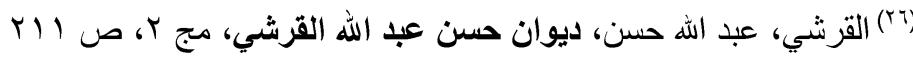

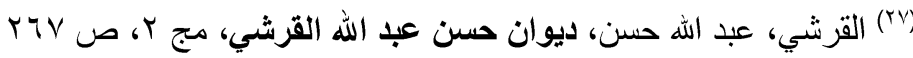

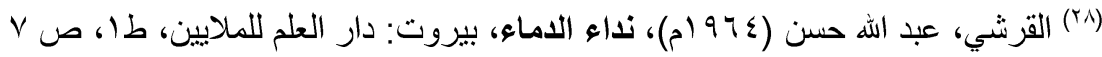

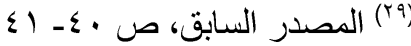

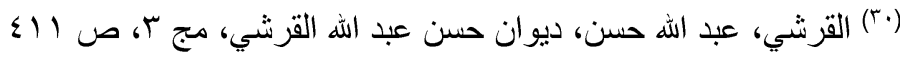

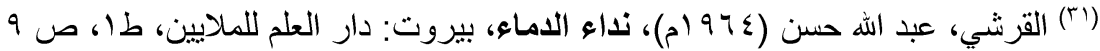

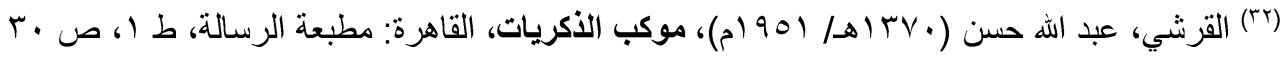

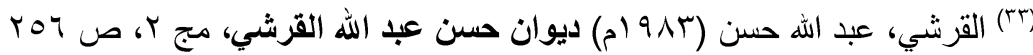

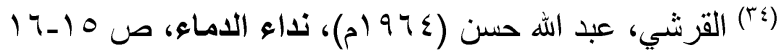

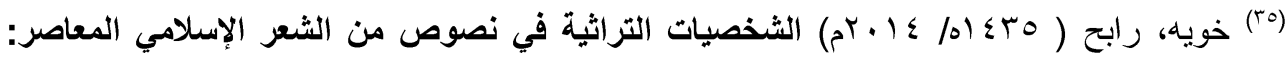

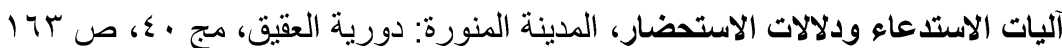

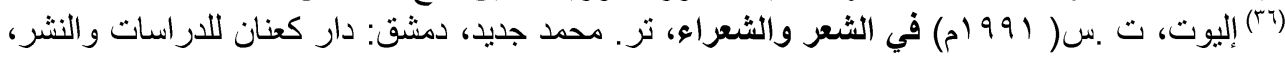




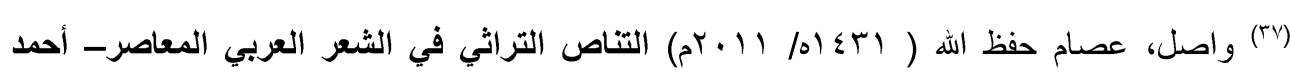

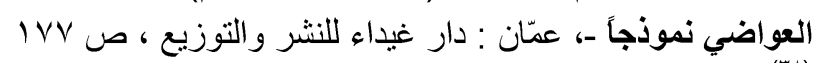

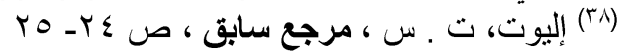

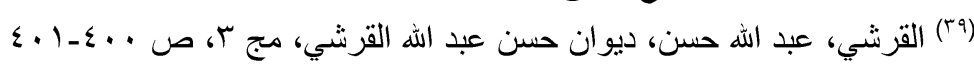

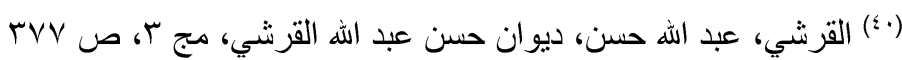

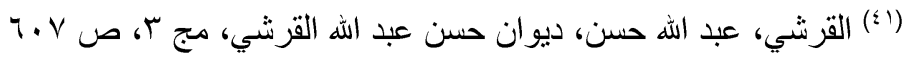

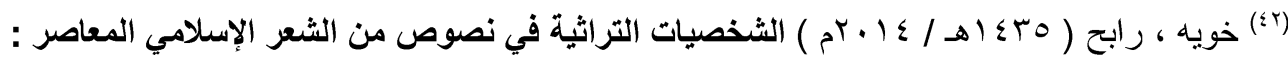

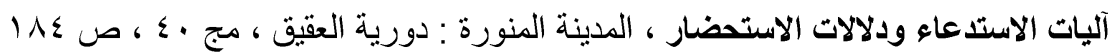

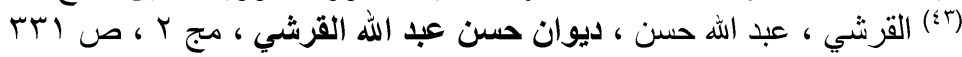

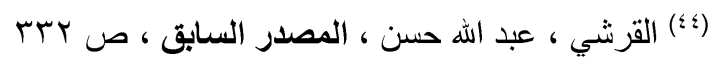

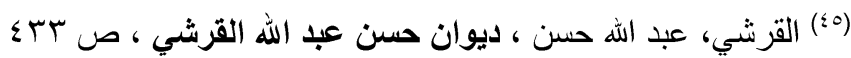

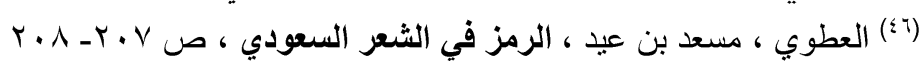

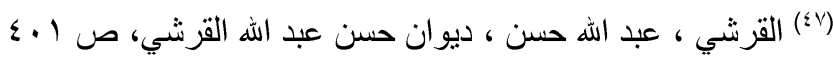

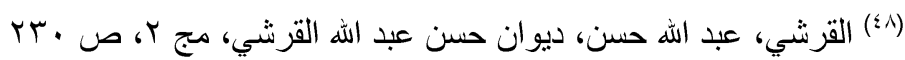

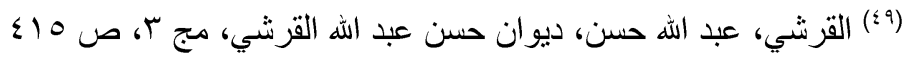

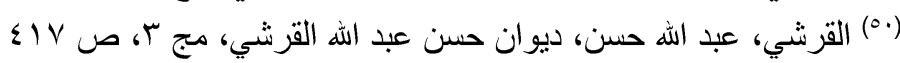

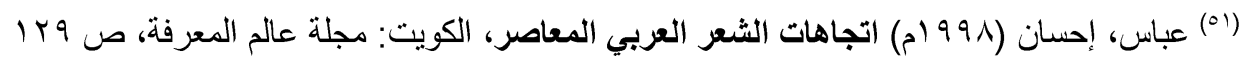

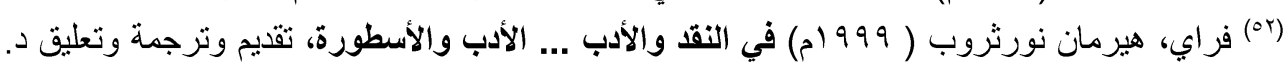

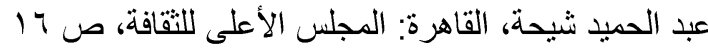

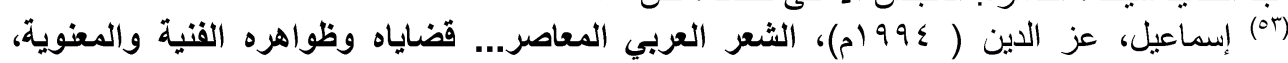

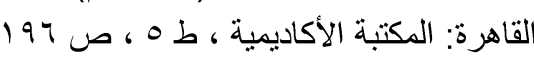

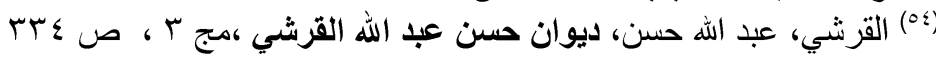
T)

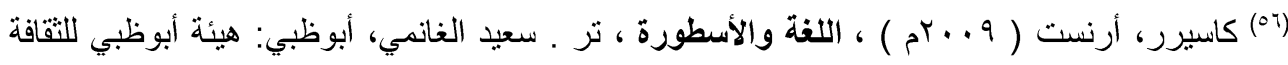

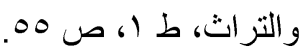

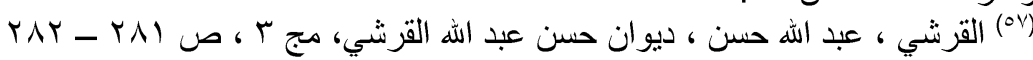

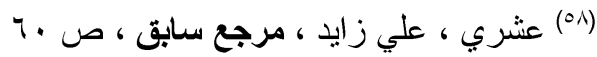

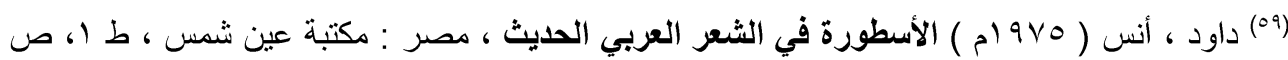

إ)

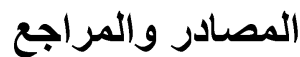

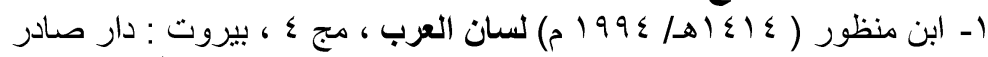

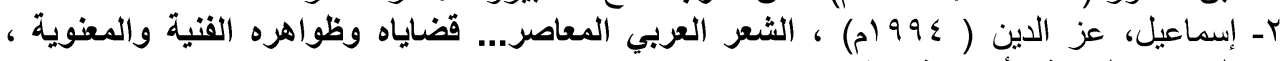

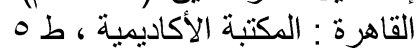

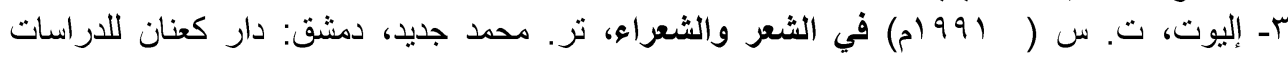

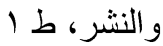

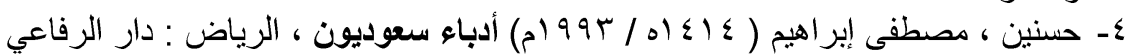

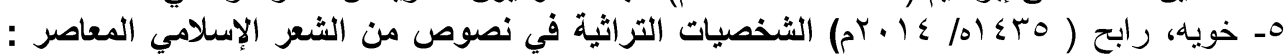

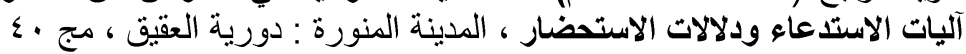




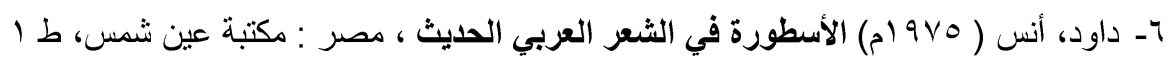

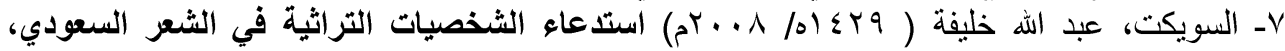

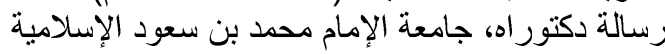

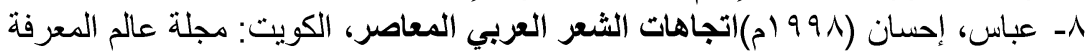

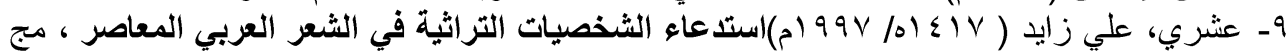

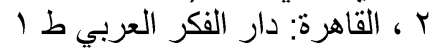

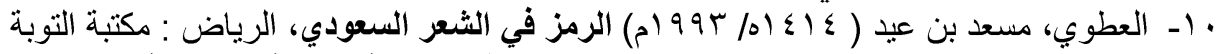

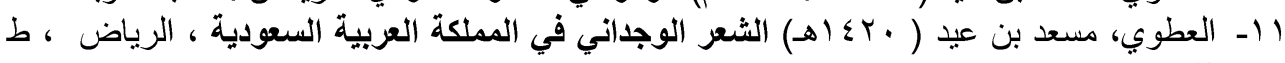

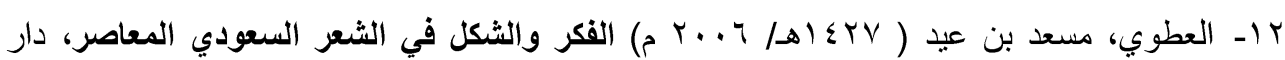

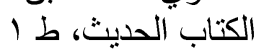

با - فراي، هيرمان نورثروب ( 999 (م) في النقد والأدب.... الأدب والأسطورة ، تقديم وترجمة وتعليق

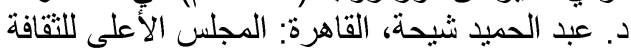

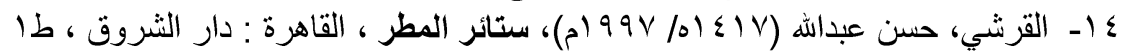

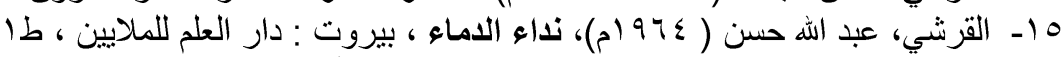

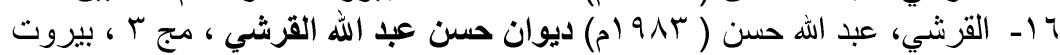

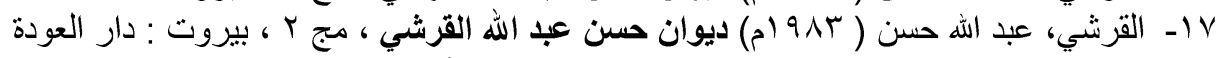

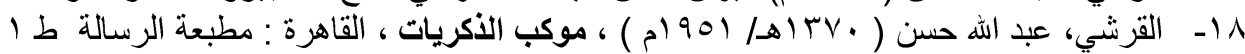

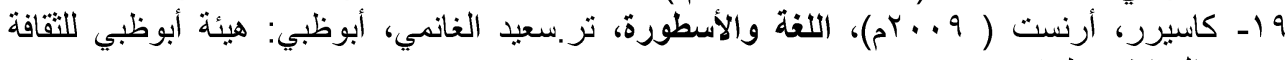

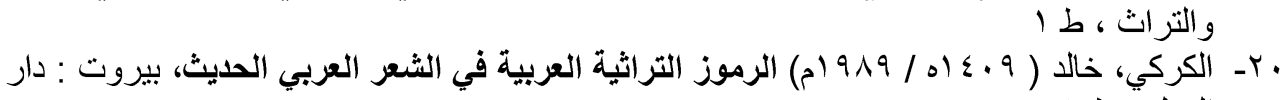

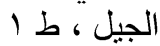

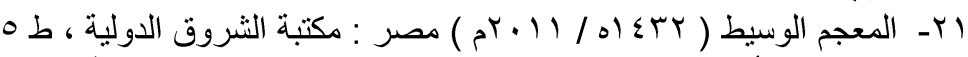

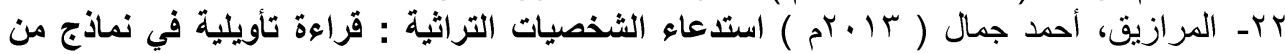

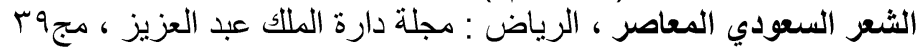

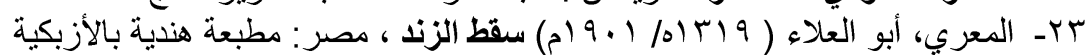

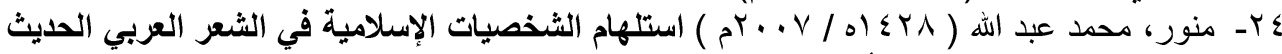

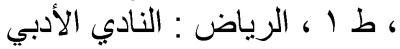

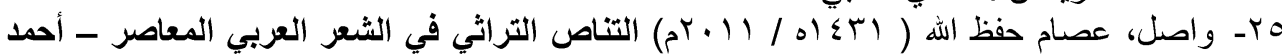

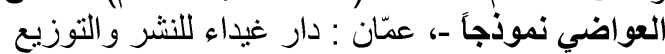

